\title{
Are Early Stage Investors Biased Against Women?
}

\author{
Michael Ewens and Richard R. Townsend*
}

October 18, 2017

\begin{abstract}
We examine whether male investors are biased against female entrepreneurs. To do so, we use a proprietary dataset from AngelList covering fundraising startups. We find that female founders are less successful with male investors compared to observably similar male founders. In contrast, the same female founders are more successful than male founders with female investors. The results do not appear to be driven by differences across founder gender in startup quality, sector focus, or risk. Given that investors are predominately male, our results suggest that an increase in female investors is likely necessary to support an increase in female entrepreneurship.
\end{abstract}

\footnotetext{
*Ewens: California Institute of Technology, mewens@caltech.edu. Townsend: University of California, San Diego, Rady School of Business, rrtownsend@ucsd.edu. The authors thank Kevin Laws of AngelList for graciously providing the data. The authors thank seminar participants at Arizona State University, Caltech, the Kauffman Emerging Scholars conference and the LBS Private Equity Symposium. We also thank Shai Bernstein, Juanita Gonzales-Uribe, Sabrina Howell, Arthur Korteweg, Ramana Nanda and David Neumark for comments.
} 


\section{Introduction}

It is well known that there is a significant gender gap in entrepreneurship. Recent studies of high-growth startup activity in the US find that only roughly 10-15\% of startups are founded by women (Tracy, 2011; Brush et al., 2014; Gompers and Wang, 2017b). Many explanations for this phenomenon have been offered, including gender differences in technical training as well as differences in risk aversion. ${ }^{1}$ According to such explanations, women drop off from entrepreneurial career paths long before they reach the point of seeking financing from a venture capitalist (VC) or angel investor. On the other hand, many have speculated that much of the gender gap may in fact be due to a lower propensity for investors to fund female entrepreneurs seeking capital. This view largely stems from the fact that over $90 \%$ of VCs are men (Gompers et al., 2014). For example, a recent article in the New York Times states that, "venture capitalists are, in a way, the gatekeepers to Silicon Valley, and if they are a group of white men [...] it is no wonder that most of the entrepreneurs fit the same mold." ${ }^{2}$ Some male investors may be reluctant to fund female entrepreneurs due to unconscious, implicit bias. Others may be overtly sexist or disrespectful towards female entrepreneurs. Highlighting the second possibility, several high profile investors, including Justin Caldbeck (Binary Capital), Chris Sacca (Lowercase Capital), and Dave McClure (500 Startups), all recently resigned amidst allegations of sexual harassment by female entrepreneurs with whom they had business dealings. These cases, combined with similar allegations at Uber and other tech companies, have brought widespread attention to the treatment of women in Silicon Valley.

Rigorously examining whether female entrepreneurs are at a disadvantage in raising capital from male investors has been difficult for several reasons. First and foremost, standard data sources only provide information on startups that have successfully raised capital, as it is challenging to systematically identify startups in the pre-financing stage. From these data, it is evident that women are

\footnotetext{
${ }^{1}$ See Marianne (2011) and Croson and Gneezy (2009) for surveys of empirical and experimental evidence of differences in risk attitudes by gender. For example, Bonin et al. (2007) find that risk preferences predict occupational sorting.

${ }^{2}$ https://www.nytimes.com/2015/04/02/business/dealbook/female-run-venture-funds-alter-the-statusquo.html?_r=0
} 
dramatically under-represented among funded entrepreneurs. However, this under-representation does not necessarily point toward differential treatment of women by investors. In particular, it may be that women are just as under-represented in the pool of those seeking funding. Some have also found that, among funded entrepreneurs, female founders are more likely to pair with female investors (e.g., Marom, Robb, and Sade, 2016). However, this also does not necessarily indicate that male investors are reluctant to fund women. It may be that male investors see fewer companies with female founders due to the nature of their networks, but are no less likely to fund the female founders that they do see. In addition, investment is a two-sided decision in that it must both be offered by an investor and accepted by an entrepreneur. It may be that female founders garner equal interest from male and female investors, but are more likely to accept funding from female investors.

A second challenge is that female-led companies may differ from male-led companies in ways that make them less favorable investments on average. To the extent that such investment characteristics are unobservable in the data, but are observable to investors, it may appear that investors are reluctant to invest in women when in fact they are screening on other attributes. Moreover, even if investors cannot observe these characteristics, but know that they correlate with gender, they may statistically discriminate against female entrepreneurs, which is distinct from taste-based discrimination.

In order to address these challenges, we use a proprietary dataset obtained from AngelList, a popular online platform started in 2010 that connects investors with seed stage startups. Companies create profiles on AngelList describing their businesses and founding teams. They can then start a fundraising campaign wherein they specify the amount of capital they are trying to raise along with other desired deal terms. Accredited investors - both angels and VCs - can register on the platform and subsequently connect with companies seeking funds. The site is widely used, even among high quality startups. By 2013, over $60 \%$ of companies raising a seed round had an AngelList profile and more than half of those firms attempted to raise capital through the site (Bernstein, Korteweg, and Laws, 2017). Many well-known companies, such as Uber and Pinterest, have raised capital through 
AngelList.

There are several advantages of this setting for studying the impact of gender on entrepreneurial fundraising. First, unlike much of the past work on this topic, we are not limited to studying startups that successfully raised capital. Instead, we observe a large set of startups that are trying to raise capital - some of which succeed and some of which fail. This allows us to characterize the population of founders seeking financing in a way that has not previously been possible, and to more directly examine whether gender appears to be an important determinant of fundraising success. Second, because our data come directly from AngelList, we also observe other investor actions that are not publicly visible. In particular, we see when an investor decides to "share" a company profile with someone else or "request an introduction" to the founders. As noted earlier, investment is a two-sided decision, but many of the other outcomes we are able to study are expressions of interest that only involve an action on the part of the investor. These actions also precede any personal interactions with founders that may differ across investors and thus complicate the analysis. Third, because of the nature of the platform, all investors have "access" to all deals in the sense that they can see the exact same information about the same set of companies and are free to take action on any company. Therefore, each investor's information and opportunity set is the same, at least with regard to the one-sided actions discussed above. Finally, we are also able to accurately observe the gender of both the founders and the investors based on their names and profile pictures. This feature of the data means that we can benchmark the behavior of male investors to that of female investors for the same set of companies. For example, if female-led companies tend to have unfavorable investment characteristics, one might expect both male and female investors to respond similarly to these characteristics.

We consistently find that female-led companies experience more difficulty garnering interest and raising capital from male investors compared to observably similar male-led companies. In particular, women are less successful with male investors, even controlling for a battery of startup/founder characteristics that encompass much of the information that was available to investors online when making the decisions we are studying. We view the establishment of this fact as major contribu- 
tion. Any debate about statistical versus taste-based discrimination begins from the premise that there is differential treatment in the first place. However, up until this point, most evidence of differential treatment in the entrepreneurship setting has been indirect at best, due to the fact that most datasets only cover startups that successfully raise capital. Both statistical and taste-based discrimination represent a causal effect of gender. Of course, disentangling the two is notoriously difficult. Nonetheless, we attempt to do so to the extent possible by taking advantage of unique aspects of our setting.

First we investigate the possibility that our results are driven by unobservable startup characteristics correlated with founder gender. In particular, we benchmark the behavior of male investors to that of female investors for the same set of companies. If male investors are not responding to gender but to unfavorable startup characteristics correlated with gender - which we are unable to control for -we should expect female investors to respond similarly to these unfavorable startup characteristics; therefore, female investors should also show less interest in female-led startups. However, we do not find this to be the case. Rather, we find that the same female-led startups in our sample are actually more likely to be shared, to receive a request for an introduction, and to ultimately get funded by female investors than observably similar male-led startups. If female investors are unbiased, this would suggest that, if anything, these female-led startups have more favorable unobservable investment characteristics. That could plausibly be the case if, for example, only the best women enter entrepreneurship due perceived difficulties for them in that field, whereas there is less positive self-selection intro entrepreneurship for men.

Still, several alternative interpretations remain possible. First, it could be that investors have a screening and/or monitoring advantage with companies led by founders of the same gender as themselves. For example, female-led companies may tend to operate in sectors that are geared toward female customers, and male investors may have less expertise in these sectors than female investors. To explore this possibility, we repeat our analysis on various sub-samples of "genderneutral" startups - for example, startups that three independent evaluators categorized as equally likely to have been founded by a man or a woman based on the non-founder sections of their 
profiles. The results are similar in these subsamples, suggesting that female entrepreneurs are at a disadvantage with male investors, even when there is nothing obviously female about their startup's business description.

Alternatively, female-led startups may have different payoff distributions than male-led startups. For example, female-led startups may offer relatively low expected payoffs but with relatively low variance as compared to male-led startups. In that case, if male investors are more risk-tolerant than female investors, they may prefer to invest in male-led startups while female investors prefer to invest in female-led startups. In order to investigate this, we examine the correlation between male and female investor interest, holding founder gender fixed. Within both the male-led-only and female-led-only startup samples, we find a strong positive correlation between female investor interest and male investor interest. This suggests that the two groups of investors evaluate companies similarly. If they targeted different payoff distributions we should instead find that, among startups with founders of a given gender, the ones female investors are interested in tend to be ones that male investors are not and vice versa.

Finally, it is also possible that female investors are motivated in part by non-financial considerations, such as a desire to help other women, while male investors are only financially motivated. In that case, male investors could be reluctant to fund female-led companies because they are worse investments, while female investors simultaneously prefer to invest in the same female-led companies. To investigate this potential explanation, we examine startup outcomes. If female investors prefer to invest in female founders due to non-financial motives, we should expect to see female-female investor-founder pairs underperform female-male pairs ex-post. Similarly, if male investors prefer to invest in male founders due to financial motives, we should expect to see male-male investor-founder pairs outperform male-female pairs ex-post. These tests are analogous to Fisman, Paravisini, and Vig (2017). Instead, we find that, for a given female investor, the female-led startups that she pairs with are statistically indistinguishable from the male-led startups she pairs with in terms of their probability of failure or probability of success (i.e., exit via IPO/acquisition). For a given male investor, the male-led startups that he pairs with, underperform the female-led startups he pairs 
with on both measures. These results suggest that, if anything, it is male investors who appear to have non-financial motivations for investing within-gender.

Overall, our results are most consistent with either (1) taste-based discrimination by male investors and no gender discrimination by female-investors or (2) taste-based discrimination by both male and female investors in favor of their own gender, i.e., "homophilistic preferences." Note that even if male and female investors have symmetric taste-based motivations for preferring to invest within-gender, such taste-based motivations are of greater concern for female founders, as the bulk of early stage investors are male. Thus, in either case, an important implication of our results would be that more female investors are likely to be necessary to support the entry of more female entrepreneurs.

It is worth pointing out that this implication would also follow, even if our baseline results were actually driven by within-gender screening/monitoring advantages that we are unable to account for empirically. That is, if female entrepreneurs tend to start businesses that are hard from male investors to understand, more female investors would be necessary to support the entry of female entrepreneurs. In that sense, even if the mechanism underlying our baseline results cannot be pinned down definitively, the results are meaningful nevertheless.

This paper contributes to a growing literature on gender and entrepreneurship. Many studies have shown that women are extremely under-represented among venture-backed entrepreneurs. Gompers and Wang (2017b) find that just 10.7\% of venture-backed founders were women from 2010-2015. Brush et al. (2014) estimate the number to be 15\% using data from 2011-2013. Defining entrepreneurship more broadly, Tracy (2011) finds that $12.4 \%$ of "high-impact" firms with less than 20 employees in $2004-2008$ were owned by women. In contrast to these papers, we are able to estimate the female share both among those who successfully raise capital but also among those seeking capital who do not succeed in raising it. In contemporaneous work, Raina (2017) asks whether venture capitalists play a role in the lower female participation in entrepreneurship. Our focus on both funded and non-funded startups allows us to separate out a larger set of alternative explanations while also isolating the role of investor gender. 
Other studies have shown that women are also underrepresented on the investor side. For example, Gompers et al. (2014) find that just $6.1 \%$ of VCs are women. This naturally begs the question of whether finance plays a role in the under-representation of women among venture-backed entrepreneurs. Coleman and Robb $(2009,2016)$ find that women who do become entrepreneurs use less external equity financing and, possibly as a result, hire fewer employees and have slower businesses grow. Brooks et al. (2014) conduct a lab experiment in which the same entrepreneurial pitch is delivered by a man and a woman and then evaluated by non-investor experiment participants. They find that participants are significantly more likely to make mock investments in male entrepreneurs than female entrepreneurs delivering the same pitch. Our paper differs in that we study real investors making equity investments in real companies. In addition, we investigate whether the gender of the investor plays a role in how the gender of the participant is evaluated. Marom, Robb, and Sade (2016) study fundraising campaigns on the crowdfunding site Kickstarter. They find evidence that men are significantly less likely than women to back women-led projects. ${ }^{3}$ Our analysis differs in that we study equity financing by angel and VC investors rather than rewardsbased crowdfunding. Thus, we seek to understand the extent to which differential treatment of women by traditional investors plays a role in explaining the previously documented entrepreneurship gender gap. In contrast, Marom, Robb, and Sade (2016) seek to understand the extent to which the advent of crowdfunding may help to democratize access to capital by dramatically changing the composition and incentives of capital providers.

The rest of the paper proceeds as follows. Section 2 provides background about AngelList. Section 3 describes the data. Section 4 discusses the results. Section 5 concludes.

\section{The AngelList Platform}

Traditionally, seed-stage startup financing has largely been done through personal networks. Founders often seek capital from potential investors who they either know directly or indirectly through a

\footnotetext{
${ }^{3}$ Greenberg and Mollick (2017) provide an explanation using both lab and observational data for why women might perform better on these platforms.
} 
mutual acquaintance. AngelList was founded in 2010 with the goal of making it easier for founders and investors to connect. Since launching, the platform has attracted much attention and grown rapidly in popularity, becoming an important part of the startup ecosystem. By 2013, over $60 \%$ of companies raising a seed round had an AngelList profile and more than half of these firms attempted to raise capital through the site (Bernstein, Korteweg, and Laws, 2017). Many well-known companies, such as Uber and Pinterest, have raised capital through AngelList.

The website allows founders to create startup profiles describing their idea, progress thus far, and personal/professional background. They can then start a fundraising campaign wherein they specify the amount of capital they are trying to raise along with other desired deal terms. Accredited investors - both angels and VCs - can register on the platform and subsequently connect with companies seeking funds. There are a variety of ways that an investor can interact with a startup. First, an investor can "share" a startup profile with someone else either another AngelList user (through a private message) or someone off the platform (through an email with an embedded link). Investors often share deals with others that they know may be interested. Since multiple investors are frequently involved in a round of financing, sharing a deal also does not necessarily preclude the sharer from investing as well. Second, an investor can request an "introduction" to a startup. If the request is accepted, the investor can communicate directly with the founders and view confidential documents such as pitch decks, financials, or in depth business plans. Absent an introduction, communication is not possible, nor is full data access. Importantly, introduction requests can only be made to startups with an active fundraising campaign. Thus, a request for an introduction can be viewed as a direct precursor to investment. Indeed, startups in our sample that receive an introduction request are five times as likely to raise capital as those that do not. Finally, an investor can "fund" a startup. This last step happens offline, although founders can and do self-report consummated financing rounds in the funding section of their startup profile. Aside from the cost of making an investment, investor actions on AngelList are costless and private. For example, there is no limit on the number of introduction requests an investor can make, and no one on the platform other than the recipient can observe the request. In addition, all investors have 
"access" to all deals in the sense that they can see the exact same information about the same set of companies and are free to take action on any company.

In recent years, AngelList has also begun facilitating financings directly through the platform with equity crowdfunding syndicates. As of the time we obtained our data from AngelList, syndicates were still a fairly nascent addition to the site. Thus, we focus exclusively on the original "social network for startups" part of the platform as described above. The only other paper we are aware of that uses AngelList's proprietary data is Bernstein, Korteweg, and Laws (2017). ${ }^{4}$ They examine how the likelihood of an investor visiting a startup's profile is affected by the inclusion or omission of certain categories of information from an email sent to investors highlighting the startup. The three categories of information they consider are the startup's founding team, its traction (i.e., performance metrics), and its existing investors. They find that that omitting information about the founding team has the biggest negative impact on investor click-through rates from emails. Given that investors on AngelList find it important to see information about the founding team, it is plausible that characteristics like founder gender may play an important role in their decision-making. In contrast to Bernstein, Korteweg, and Laws (2017), we use the full AngelList dataset rather than focusing on the small set of companies featured in emails. We also study a broader set of investor actions that are more closely tied to investment rather than email clicks.

\section{Data}

In this section we describe our key variables, data sources, and sample restrictions.

\subsection{Investor-startup interactions}

As described in Section 2, investors on AngelList can interact with startups in several ways that signal interest. We focus on investor sharing, requests for introductions, and investment. Data on sharing and introduction requests come directly from AngelList. However, as described above,

\footnotetext{
${ }^{4}$ Other papers have used data on AngelList, however, they are usually scraped from the website. Such data is thus lacking failed fundraising and removed profiles, which are included in our sample. More importantly, scraping the site does not reveal the signals of interest - sharing and introductions - that we use.
} 
actual investments occur offline. Therefore, AngelList's data on investment is user-entered and somewhat incomplete.

We thus supplement AngelList's investment data with three additional sources. First, we match our sample with startups in Dow Jones' VentureSource database. This allows us to identify companies in our sample that eventually raised money from VCs. Second, we match our sample to startups that report raising capital on Crunchbase. Crunchbase's coverage is likely to be better than VentureSource for seed rounds with no institutional investor. Finally, to further ensure that we capture seed rounds as well as possible, we also match our sample with fundraising data gathered directly from SEC Form D filings. In principle, these filings are required for all private equity financings. ${ }^{5}$ Throughout the paper, our analysis of fundraising outcomes uses all of these data sources. However, our results remain similar when only using investment data from AngelList as well (see Appendix Table A2).

Using all data sources, we find that $13.3 \%$ of startups with an AngelList fundraising campaign subsequently obtain funding. This compares to a fundraising rate of $8.4 \%$ using only AngelList investment data. Because we are interested in separately analyzing the behavior of male and female investors, we focus primarily on funding events for which we can identify the gender of the investor. Unfortunately, our data sources often fail to identify the individual investors involved in a round. This either happens because no investors are identified (only the fact that a financing round occurred is recorded by the data source), or because the investors identified are institutions rather than individuals. ${ }^{6}$ Overall, we are only able to identify investor gender for $27 \%$ of successful financing rounds.

\footnotetext{
${ }^{5}$ Matching with VentureSource and Crunchbase is based on a cleaned version of a startup's web domain. Matching with Form D filings is based on location, founding date, and company name.

${ }^{6}$ For institutional financing rounds from VentureSource, we are able determine the gender of the individual investor who sourced the deal using board membership. That is, we assume the individuals who took board seats in the first financing round were the ones who sourced the deal.
} 


\subsection{Startup outcomes}

We focus on two measures of startup outcomes following a fundraising campaign. The first is an indicator equal to one if a startup has failed, based on whether its website is no longer active as of November 2016. We deem a website as inactive if it fails to load and/or if its domain is available for purchase. The second measure of startup outcomes is an indicator equal to one if a startup has had a successful exit via IPO or acquisition according to VentureSource or Crunchbase. Successful exits are quite rare in our sample. Some $4.6 \%$ of firms that raised capital in our sample had a successful exit by November 2016. This is likely due to the fact that AngelList is relatively new, so even the high performing companies that originally raised capital through the site have not had enough time to have an IPO or acquisition.

\subsection{Identifying gender}

We identify the gender of founders and investors in our sample based on their name and profile picture. In particular, we run all first names through the genderize.io API, which gives the probability a first name corresponds to a woman based on a large sample. ${ }^{7}$ For individuals with names that are at all ambiguous $(0<\operatorname{Prob}($ Female $)<1)$, we determine gender based on the user's profile picture. To do this, we use Crowdflower, which is a service like Amazon Mechanical Turk with additional quality controls. In particular, "test pictures" for which the correct answer has already been determined by us are randomly mixed in with pictures that have not been categorized. Crowdflower contributors who fail too many test questions are excluded, and the work of less trusted contributors is double-checked by more trusted contributors.

While we observe gender at the founder level, the outcomes we examine are at the startup level. Therefore it is necessary to assign a gender to a startup. Many of the startups in our sample have a single founder, in which case it is straightforward to categorize a startup as "female-led" or "male-led" based on the gender of that founder. Some of the startups in our sample have multiple founders. In these cases we categorize startups based on the gender of the founder who is also listed as the

\footnotetext{
${ }^{7}$ http://genderize.io
} 
CEO. As we will show, we find similar results whether or not we restrict attention to single-founder companies.

\subsection{Non-gender founder characteristics}

A founder's AngelList profile can include a short bio with information on their education and past work experience. Founders often provide only sparse information about themselves on AngelList and instead use the option to link their AngelList profile to their LinkedIn profile. In addition, for some of the founders who do not link the two profiles, we are still able to find their LinkedIn profile manually by searching LinkedIn for their name along with the name of their AngelList startup. Overall, we are able to find a LinkedIn profile for $62 \%$ of our sample, although these profiles vary in terms of which categories of information are included. ${ }^{8}$

When educational information is included, we can observe the schools a founder attended, degrees obtained, and years of graduation. When we observe the year of college graduation, this provides a fairly accurate proxy for age (assuming individuals are 22 at graduation). We crudely categorize founders as having attended an "elite" school if they hold a degree from a top-10 university according to the 2017 U.S. News \& World Report rankings. In terms of work experience, we can observe the number of jobs held, past job titles, and number of years in the work force. We categorize individuals as previous founders if they held the title of founder at a different company prior to their AngelList fundraising campaign. Appendix Table A1 provides a full listing of these background variables.

\subsection{Sector and location classification}

Startups on AngelList describe themselves in part through various categories of keyword "tags." There are 1,805 distinct sector tags and companies can use multiple tags in combination to describe themselves. We map these tag combinations into VentureSource sector categorizations using the subsample of AngelList startups that also appear in VentureSource. For startups in the overlapping

\footnotetext{
${ }^{8}$ Public profiles were searched and evaluated manually by an RA.
} 
sample we already have both AngelList tags and VentureSource industries. For startups that are not in the overlapping sample (i.e., only in AngelList) we identify the nearest neighbors in the overlapping sample. ${ }^{9}$ Based on these nearest neighbors we compute a probability distribution for each company over the seven major VentureSource industries. We then categorize a company according to its most probable VentureSource sector. ${ }^{10}$ We also do the same using VentureSource 18-sector and 43-sector categorization schemes.

Startups use 5,841 distinct location tags. We geocode these using the google maps API and then categorize them according to the 19-region scheme used by the National Venture Capital Association (NVCA). The NVCA regions are coarse where there are few startups and more granular where there are many. For example, there is one region in the Southwest, but four regions in California.

\subsection{Final sample}

The final sample of founders and startups satisfies several conditions that help to minimize measurement error and captures a representative set of startups seeking capital in our sample period. The sample begins with all first-time fundraising events for US startups founded between 2010 and November 2015. Next, we require that AngelList have a founding team where we could confidently identify the gender of each founder. Any startup that raised venture capital before our sample period is excluded to ensure we study first-time financings. The startup's fundraising campaign must also have a non-missing capital sought and a non-missing business description in their profile.

Finally, we require that the startup maps to a VentureSource sector and NVCA region based on its tags. In the end we have 17,780 startups in the sample.

\footnotetext{
${ }^{9}$ Nearest neighbors are startups with the highest number of common AngelList tags.

${ }^{10}$ Our results are similar whether we control directly for the sector probabilities, or assign according to the most probable.
} 


\section{Results}

\subsection{Summary statistics}

We begin in Table 1 by examining the gender composition of entrepreneurs and investors. As mentioned earlier, standard datasets do not cover those who have yet to successfully raise capital. This restriction makes it impossible to assess the extent to which the gender gap that has been documented previously among funded entrepreneurs is also present among the pool of those seeking funding. In our data we can observe a large sample of entrepreneurs seeking funding. This allows us to get a sense of the point in the entrepreneurial pipeline where women appear to (differentially) drop out. We view these simple summary statistics as an important contribution in and of themselves. Overall, we find that only $15.8 \%$ of founder CEOs who try to raise capital on AngelList are women (21\% of all founders, including non-CEOs). This suggests that, in fact, much of the gender gap is already present before investors get directly involved. It should also be noted that the barriers to fundraising on AngelList are arguably lower than the barriers to any other type of fundraising. Therefore, this number likely represents an upper bound. That is, women are likely even more under-represented among those approaching investors in the traditional manner. This large prefunding gender gap suggests that non-finance factors may account for a large portion of the overall entrepreneurship gender gap (e.g., Gompers and Wang, 2017b). These factors may include innate differences between women and men or differences that arise due to differential treatment of women earlier in the entrepreneurial pipeline. However, it is also quite possible that many women would be interested in raising capital for an entrepreneurial venture but are discouraged by the difficult fundraising environment they face, and so do not even try.

Table 1 also shows the gender composition of entrepreneurs in datasets that mainly cover funded startups: Crunchbase and VentureSource. Both have a lower fraction of female founders in terms of both founder CEOs or founding team than AngelList. It is also interesting to examine the gender composition of investors across the three datasets. We find that some $8 \%$ of investors with some sharing, introduction or funding activity on the AngelList platform are women. This 
number is lower than the female founder share, however, it exceeds that in the alternative datasets. This difference with Crunchbase and particularly VentureSource provides some evidence that the AngelList platform may have lowered barriers to entry for female investors.

Table 2 presents summary statistics separately for the male- and female-led startups in our sample. Panel A shows startup characteristics, Panel B shows startup outcomes, and Panel C shows founder characteristics. The two groups are fairly similar on many dimensions. The main difference in startup characteristics that we find is that male-led startups generally set higher fundraising targets $(\$ 690,000$ vs $\$ 530,000)$. In terms of outcomes, most startups that post a fundraising campaign appear to generate relatively low levels of interest from investors. Nonetheless, men are more successful than women in terms of generating interest. In particular male-led companies are more likely to be shared by a male investor ( $14 \%$ vs $4 \%$ ), to receive an introduction request from a male investor (18\% vs $14 \%)$, or get funded by a male investor $(3.6 \%$ vs $1.6 \%) .{ }^{11}$ Male-led companies are slightly more likely to have had an IPO or Acquisition (.8\% vs .6\%) and are slightly less likely to have already failed ( $46 \%$ vs $48 \%$ ). The average male founder in our sample is similar to the average female founder in terms of age (35.26 vs 33.69), years of work experience (13.5 vs 12.86), number of previous jobs held (4.61 vs 4.63), and number of co-founders (0.32 vs 0.23$)$.

The two groups also have similar levels of educational attainment and previous founder experience. In particular male and female founders are similarly likely to hold a bachelor's degree (48\% vs $49 \%$ ), MBA degree ( $8 \%$ vs $8 \%$ ), or other advanced degree (4\% vs $3 \%$ ). Likewise, they have similar previous founding experience (18\% vs 13\%). The education and founder experience variables are based on the information founders post on AngelList as well as LinkedIn. It is possible that actual educational attainment or founder experience in our sample is higher than reported if some founders choose to omit this information from the two online profiles. Nonetheless, we interpret these variables as reflecting the information that was available to investors at the time of the fundraising campaign. This is likely the information upon which investors decided to share or request an intro-

\footnotetext{
${ }^{11}$ As noted in Section 3.1, many rounds in the data have unknown investors. Therefore these fundraising success rates are understated. When including unknown investors, the fundraising success rates are $13.7 \%$ and $11.4 \%$ for male and female founders, respectively.
} 
duction to a company and thus is the appropriate information to control for in regressions where those are the outcome variables. In the process of actually funding a company, investors likely learn additional information from conversations with the founders. Thus, when fundraising success is our outcome variable, our ability to control for the information available to investors is more limited.

Table 3 compares the characteristics of male and female investors on AngelList. As with founders, we find that male and female investors are similar in terms of age, experience, and education. For the purpose of these summary statistics we limit the sample to investors who made at least one introduction request and who linked their LinkedIn profile with their AngelList profile. However, the subsequent analysis will include investors for whom we lack LinkedIn data.

\subsection{Interactions between founders and male investors}

We now explore in a regression framework whether the interest a startup receives from investors correlates with the gender of its founder. Specifically, we estimate equations of the form:

$$
y_{i}=\alpha+\beta \text { Female }_{i}+\boldsymbol{\delta}^{\prime} \mathbf{X}_{\mathbf{i}}+\epsilon_{i},
$$

Where $i$ indexes startups, $y$ represents various startup-level outcomes, Female is an indicator variable equal to one if the startup has a female founder-CEO, and $\mathbf{X}$ represents a vector of startupand founder-level controls. ${ }^{12}$ We focus first on outcomes involving interest from male investors only. We do this because male investors are more likely than female investors to exhibit bias against female founders. Such bias would also be particularly consequential given that the bulk of investors are male.

We begin in Table 4 by using investor sharing of a startup profile as a proxy for interest. Because our sample consists only of startups that are raising capital, the sharing events we observe likely represent communications among investors regarding the opportunity to invest. Despite the low

\footnotetext{
${ }^{12}$ Observations in Equation 1 are at the startup-level. We could have alternatively estimated equations at the startup-investor pair level. However, this would require that each startup observation be repeated for each investor on AngelList. Given the large number of investors on AngelList, doing pairwise analysis becomes computationally difficult. Moreover, the pairwise analysis offers little advantage over the startup-level analysis, as the two are mechanically linked.
} 
cost of sharing on the platform, only about $12.3 \%$ of startups in our sample were shared by an investor. This investor selectivity with sharing suggests that sharing may indeed be a good measure of interest. We then regress a "shared by male investor" indicator on a "female founder" indicator. As mentioned earlier, for companies with multiple founders, we consider the CEO to be focal. That is, the female founder indicator and all other founder-level controls correspond to the CEO.

In column (1) we include only minimal controls. Specifically, we include fixed effects for the year the startup joined AngelList and the year it posted its first fundraising campaign. These fixed effects account for the fact that older companies have had more time to generate interest among investors. We find that, on average, female-led companies are less likely to be shared by male investors, with differences significant at the $1 \%$ level. In terms of economic magnitudes, the coefficient suggest that female led companies are approximately $8 \%$ less likely to be shared, which is quite large relative to a base sharing rate of $12.3 \%$. In column (2), we control for the amount of capital sought as well as team size, sector, and location fixed effects. With the inclusion of these controls, the estimated coefficient on the female founder indicator changes little. The coefficient also remains similar as we add additional controls for education and experience in column (3). Note that the education and experience coefficient estimates have the expected sign. Startups founded by college graduates are more likely to be shared, as are startups founded by individuals who hold a degree from an "elite" university, and startups founded by repeat founders. For robustness, we also check in column (4) whether our results hold when the sample is restricted to only include startups with a solo founder, where the focal founder is unambiguous. We again estimate a similar coefficient on the female founder indicator in this restricted sample.

Finally, another form of differential treatment across genders would be a differential response by investors to the same credentials for men and women. For example, one could imagine that women benefit less than men from having attended an elite university in terms of generating investor interest. Such differential treatment would be along the lines of Bertrand and Mullainathan's (2004) finding that employers are less responsive to resume quality for job applicants with AfricanAmerican sounding names. To investigate whether a similar pattern holds in our setting, we allow 
the education and experience variables to interact with the female indicator in column (5). Overall, we find only weak evidence of credential discounting. While most of the coefficients on the estimated interaction terms are negative, they are not statistically significant. The only exception is the interaction with the previous founder indicator, which is negative and statistically significant, suggesting that women benefit less than men from having founded a startup previously. However, the economic magnitude of the coefficient is small.

While the sharing behavior of investors is interesting to examine, the way in which sharing relates to investment is unclear. It may be the case that observably similar female-led startups are less likely to be shared, but when it comes to actually raising capital, female-led companies do the same or better. To move one step closer to actual investment, Table 5 examines requests for introductions by male investors. Such requests are a direct precursor to funding, as investors need to request an introduction in order to communicate with a startup's founder(s). We find qualitatively similar results to those in Table 4. Across all specifications, female-led companies are approximately 1.5-3.5\% less likely to receive a request for an introduction, as compared to a baseline introduction rate of $17.6 \%$. Again, companies led by repeat founders, founders with a college degree, and founders who attended an elite university are more likely to receive requests for introductions. There is also again little evidence that such credentials are discounted for women.

Finally, it remains possible that although male founders appear to do better than female founders in getting early indications of interest from male investors, they do no better when it comes to actually getting funded. While investment is perhaps more important than investor sharing or introduction requests as an outcome, it is also more complex. Investment involves communication that is unobservable to us, making it difficult to control for an investor's information set. Investment is also a two-sided decision where an investor must make an offer and a founder must accept it. This means that investment could partially reflect the preferences of founders rather than investors. Finally, we observe investment with more measurement error than sharing and introduction requests, because much of the data are self-reported. With these caveats, in Table 6 we examine actual fundraising outcomes. 
Again, the results that are qualitatively similar to before. After controlling for observable firm, founder and financing characteristics, female-led startups are significantly less likely than male-led startups to raise a round from a male investor. Thus, the previous results do not appear to have been driven by the preliminary or lower stakes nature of investor sharing and introduction requests relative to actual investment. In terms of magnitudes, the estimated coefficients suggest a $0.6-1.7 \%$ decline in fundraising success on a base fundraising success rate (from an investor with a known gender) of $3.3 \%$. Thus, the difference in outcomes for female founders is economically quite large.

Overall, we consistently find that female-led companies have significantly more difficulty garnering interest and raising capital from male investors compared to observably similar male-led companies. We view the establishment of this fact as an important contribution. Any debate about statistical versus taste-based discrimination begins from the premise that there is differential treatment in the first place. However, up until this point, most evidence of differential treatment in the entrepreneurship setting has been indirect at best, due to the fact that most datasets only cover startups that successfully raise capital.

\subsection{Potential explanations}

There are, of course, many potential explanations for the baseline results presented in the previous section. We now explore these potential explanations. In particular, we consider the most likely explanations that involve male investors having purely financial motives.

\subsubsection{Differences in startup quality}

First, it is possible that female-led startups tend to have undesirable investment characteristics, which male investors respond to, and which we have not controlled for. Investors may either screen directly on these characteristics if they can observe them, or they may screen indirectly on these characteristics if they cannot observe them-by statistically discriminating against female founders. In the former case, our baseline results would represent a spurious correlation driven by omitted variable bias. In the latter case, our results would represent a causal effect, but not a 
taste-driven one. ${ }^{13}$ We note again that, in our setting, prior to the acceptance of an introduction request, we observe the exact same information as investors, which helps to reduce concerns about direct screening on characteristics that investors observe but we do not. In Appendix Table A3, we show that our results remain similar when we include an even more exhaustive set of controls, including the number of characters in the product description and additional information gleaned from LinkedIn. ${ }^{14}$ Nonetheless, it is possible that investors screen on characteristics that we do observe in the data but are unable to fully codify and control for.

To further investigate such explanations, we benchmark the behavior of male investors to that of female investors for the same set of companies. That is, the outcomes we now examine are whether a startup was shared by a female investor, received an introduction request from a female investor, or was funded by a female investor. This analysis is similar in spirit to the inclusion of startup fixed effects to control for unobservable startup characteristics. We are using the exact same sample and regression specifications as before and are thus comparing the relative investor interest drawn by the same female- and male-led startups. We are only changing the gender of the investors evaluating the companies. If male investors are not responding to gender but to unfavorable startup characteristics correlated with gender - which they may or may not observe - we should expect female investors to respond similarly to these unfavorable startup characteristics.

However, as shown in Table 7, we do not find this to be the case. Rather, across the same regression specifications as before, we find that the female-led startups in our sample are actually more likely to be shared, to receive an introduction request, and to get funded by female investors than their observably similar male-led counterparts. If female investors are unbiased, these results would suggest that, if anything, the female-led startups in our sample have more favorable unobservable investment characteristics. For example, there may be more positive self-selection into

\footnotetext{
${ }^{13}$ In the case of omitted variable bias, the negative coefficient we estimate on the female indicator would go to zero using data generated by an experiment that randomized the gender of the founder displayed to investors, holding all other aspects of a startup profile constant. In the case of statistical discrimination, such experimentally generated data would lead to similar estimates.

${ }^{14}$ We exclude some of the LinkedIn controls from the baseline regressions because they are often missing. In Appendix Table A3, when the LinkedIn variables are missing, we dummy them out rather than dropping observations, so as to maximize statistical power. That is, we replace the missing values with their own fixed effects. See Bailey et al. (2017) for an example of this type of analysis.
} 
entrepreneurship among women than men. In particular, it may be that only the most talented women enter entrepreneurship due the perceived difficulties they face in pursuing that career path.

Overall, both of the potential explanations for our baseline results discussed above- omitted variables and statistical discrimination - are encompassed by the joint hypothesis that (1) investors have purely financial motives and (2) they are reluctant to fund female-led startups because they are worse investments. The results in Table 7 are inconsistent with this joint hypothesis.

\subsubsection{Differences in sector focus}

In light of the differential behavior of male and female investors documented above, another potential explanation consistent with our findings thus far would be encompassed by the joint hypothesis that (1) investors have purely financial motives and (2) male investors are reluctant to fund female-led startups because these companies do not align with their expertise. That is, female-led startups may not be worse investments per se, but they may still differ in ways that are unappealing to male investors (and appealing to female investors).

For example, female-led startups may tend to operate in industries that are geared predominantly toward female customers, and male investors may have less expertise in these industries than female investors. In that case, male investors would potentially be at a disadvantage in terms of screening and/or monitoring companies led by female founders. We perform a variety of tests to try to explore this possibility.

Recall that companies on AngelList describe themselves with a combination of multiple keyword tags. The tags are very granular as evidenced by the fact that there are over 1,800 of them. In Panel A of Table 8, we remove startups from the sample that use any tag that is predominantly associated with one gender. We define a tag to be predominantly female if more than $32 \%$ of startups using that tag are female-led. Similarly, we define a tag to be predominantly male if less than $8 \%$ of startups using that tag are female-led. ${ }^{15}$ The two cutoffs represent double and half the percentage of founders on AngelList that are female, respectively, as we are trying to identify

\footnotetext{
${ }^{15}$ Examples of predominantly female tags include "bridal community," "mothers," "child care," and "lingerie." Examples of of predominantly male tags include "cars," "console gaming," and "proximity services."
} 
tags where women are either over- or under-represented. The idea behind this test is that, while male investors may have less insight into a female-led cosmetics company, or more insight into a male-led facial hair grooming company, they should have no differential insight into a male- or female-led biotech company, and thus the gender of the founder should not matter in that case. However, even in this restricted subsample of "gender-neutral" startups, we continue to find that male investors show less interest in female-led companies. At the same time, we also continue to find that female investors show more interest in female-led startups, suggesting that the behavior of male investors in this subsample is not due to poor investment characteristics for women working outside of predominantly female industries. Appendix Table A4 shows a second test along the same lines. In this case, we exclude all startups whose keyword tags map to consumer-related industries, as categorized by VentureSource. We map AngelList tags to VentureSource sector categorizations as described in Section 3.5. The idea behind this test is to try to remove startups from the sample that even have a potential gender component, regardless of whether they actually do. We again find very similar results in this restricted subsample.

In Panel B of Table 8, rather than trying to limit the sample to gender-neutral startups, we instead control directly for the way a company describes itself on AngelList by including a full set of tag combination fixed effects. This means that we identify only off of variation in founder gender among companies that describe themselves in the same way. We again find similar results with these granular controls. That is, even among companies that describe themselves in the same way on AngelList, male investors show less interest in female-led companies.

The above tag-based tests are still imperfect, as tags only represent part of the information available to investors. To address this concern we manually categorize startups based on the entire contents of their AngelList profile, excluding the founder section. Specifically, we used CrowdFlower to obtain three "trusted judgements" from US-based human contributors with the highest quality track record on similar "human intelligence tasks" (based on past experience and accuracy). ${ }^{16}$ After

\footnotetext{
${ }^{16}$ Contributor quality is determined on a scale of 1 to 3 by CrowdFlower based on experience and accuracy. We only allowed the highest quality contributors to participate. To further ensure contributors were actually trying to answer the questions correctly, $20 \%$ of the questions any given respondent answered were test questions where
} 
showing contributors all non-founder portions of a startup's AngelList profile, we ask them the following question:

Based on the description of the company, would you guess that the founder of this company is: (1) Highly likely to be female (2) Fairly likely to be female (3) Equally likely to be male or female (4) Fairly likely to be male (5) Highly likely to be male

We find that the trusted judgements of the human contributors were predictive of the true gender of the founder. When we regress the true gender of a startup's founder on indicator variables corresponding to the first four responses to the question above, we find that the probability that the founder is female increases monotonically with the evaluators' subjective assessment. At the extremes, startups labelled as highly likely to be female are five times more likely to actually have a female founder than startups that were labelled as highly likely to have a male founder. Probability differences from the omitted category ("Highly likely male") are statistically significant at the $1 \%$ level in all cases.

We use these data as conservatively as possible by limiting the sample to startups that all three contributors unanimously categorized as "equally likely to be male or female." Only $24 \%$ of our original sample remains after this restriction. Nonetheless, as shown in Panel $\mathrm{C}$ of Table 8, we continue to find similar results in this subsample. Appendix Table A5 shows that we also find similar results when, rather than requiring unanimity, we instead limit the sample to startups with a neutral mean response (i.e. a mean response strictly greater than 2 and strictly less than 4). Together, the above evidence suggests that our baseline results are not driven by differences in sector focus that are not captured by the controls used in our main specifications.

the founder's gender was obvious (e.g., because it was explicitly identified in one of the non-founder portions of the startup's AngelList profile). The judgements of those who failed more than $10 \%$ of these test questions were categorized as "untrusted judgements," as were judgements that were reached too quickly ( $<60$ seconds). These untrusted judgements were excluded from the analysis. 


\subsubsection{Differences in payoff distribution}

The evidence thus far suggests that male investors show less interest in female-led companies regardless of sector. Another, more subtle, possibility is that female-led startups may have a different payoff distribution than male-led startups. For example, female-led startups may offer relatively low expected payoffs but with relatively low variance as compared to male-led startups. In that case, if male investors are more risk-tolerant than female investors, they may prefer to invest in male-led startups while female investors prefer to invest in female-led startups. This explanation is summarized by the joint hypothesis that (1) investors have purely financial motives and (2) male investors are reluctant to fund female-led startups because these companies do not align with their risk-preferences. ${ }^{17}$ Of course, it should be noted that, since all of the companies in our sample are early stage, they are all quite risky in the sense that they are highly likely to fail without any capital recouped by investors. Moreover, the investors in our sample are all self-selected to be fairly wealthy and risk-tolerant.

Nonetheless, in order to investigate whether gender differences in startup payoff distributions and investor risk preferences drive our results, we examine the correlation between male and female investor interest, holding founder gender fixed. First, we limit the sample to include only male-led startups. Within this all male-led sample we re-run our baseline regressions, replacing the female founder indicator with a female investor interest indicator corresponding to the outcome under study (i.e. an indicator equal to one if the male-led startup was shared by a female investor, received an introduction request from a female investor, or was funded by a female investor, respectively). If in fact male and female investors target startups with different risk-reward profiles, we should estimate a negative coefficient on the female investor interest indicator; among male-led startups, those that female investors are interested in should tend to be ones that male investors are not and vice versa. However, as shown in Panel A of Table 9, we instead find a strong positive coefficient on the female investor interest indicator, significant at the $1 \%$ level. This suggests that, holding founder gender

\footnotetext{
${ }^{17}$ Under this joint hypothesis, it cannot be that female-led startups offer the same expected payoffs with lower variance, or higher expected payoffs with the same variance. If that were the case male investors with solely financial (mean-variance optimizing) motives would prefer these startups as well.
} 
fixed, the two groups of investors have similar investment objectives.

In panel $\mathrm{B}$ of Table 9, we repeat the analysis, here limiting the sample to include only femaleled startups. The results are similar. Note that these estimates cannot be driven by male and female investors having opposing payoff distribution targets that are simply dominated by a separate shared objective to invest in "high quality" startups. Startup quality is embedded in the payoff distribution. Loosely speaking, for an investor with purely financial motives - as assumed under the joint hypothesis stated at the beginning of this section - a high quality startup is one with high expected payoffs and low variance. Put differently, an investor with purely financial motives should only care about a company's payoff distribution and should not have a separate, more heavily weighted, investment criterion.

\subsubsection{Differences in investor motives}

Another potential explanation for our results relaxes the assumption that all investors have purely financial motives. This explanation is encompassed up by the joint hypothesis that (1) male investors have purely financial motives, while female investors have both financial and non-financial motives and (2) male investors are reluctant to fund female-led startups because they are worse investments, while female investors derive utility from funding female-led startups. Note that, unlike the previous explanations we have explored, this explanation requires that male and female investors have different motives.

Related to the joint hypothesis above, there are in fact a handful of early stage funds that have an explicit social mission of supporting entrepreneurship by women. It is possible female investors are predominantly associated with such funds and thus have different incentives than their male counterparts. To investigate this, we manually compiled a list of known female-focused angel and VC funds. ${ }^{18}$ We find that only $2 \%$ of the female investors in our data are associated with such funds

\footnotetext{
${ }^{18}$ These funds are: Valor Ventures, Golden Seeds, Pipeline Angels, Built By Girls Ventures, BELLE Capital USA, Female Founders Fund, The Womens' Venture Capital Fund, Forerunner Ventures, 500 Women, Angel Academe, Phenomenelle Angels Fund, Broadway Angels, Topstone Angels, Plum Alley, The Jump Fund, Astia, Scale, Cross Culture Ventures, Gotham Gal Ventures, True Wealth Ventures, Halogen Ventures, Sofia Fund, Female Funders, Women Angels, Women Founders Network, Women Launch and Women Lead Inc.
} 
( $0.5 \%$ of those that made least one introduction request). Appendix Table A6 shows our baseline results excluding these investors. As can be seen, the results change little. Nonetheless, it may be the case that female investors not associated with such funds still invest with social objectives in mind.

To further investigate whether our results are driven by non-financial motives, we examine startup outcomes. If female investors prefer to invest in female founders due to non-financial motives, we should expect to see female-female investor-founder pairs underperform female-male pairs expost. Similarly, if male investors prefer to invest in male founders due to financial motives, we should expect to see male-male investor-founder pairs outperform male-female pairs ex-post. This test is along the lines of Fisman, Paravisini, and Vig (2017) who examine whether loan officers in India show a preference for within-caste lending due to financial or non-financial motives by comparing the ex-post loan performance of within-caste and across-caste loans.

We face a few challenges in implementing this test. First, as mentioned earlier, investment is a two-sided decision. Therefore, if one defines realized pairs based on investment, it is unclear whether performance differences are driven by the way that investors select entrepreneurs or vice versa. To get around this issue, we define realized pairs based on investor introduction requests. A second challenge is that few companies in our sample have had a successful exit at this point in time, likely due to the recency of the platform. While early successes are relatively uncommon, early failures are not. Therefore, in addition to success we also look at failure. As described in section 3.2, we define a startup to have failed if its website was no longer active as of November 2016. All regressions include year fixed effects based on the year a startup joined AngelList to address the concern that startups from different cohorts will have differential failure rates as of November 2016 due to age differences on that date.

The results are shown in Table 10. Observations are now at the startup-investor pair level and there is one observation for every realized pair based on introduction requests. The variable of interest, "Same gender," is an indicator variable equal to one if the founder and investor are of the same gender. We include investor fixed effects in the even columns, and therefore compare the 
performance of same gender and cross-gender pairs involving the same investor. The regressions also include a new investor-founder pair variable "Interest overlap" which is the cosine similarity between the investor's stated interests and those of the founder. ${ }^{19}$ This variable helps address any matching on sector, skill or location preferences between investor-founder pairs. Each panel of the table reports a different company outcome variable. In Panel A the outcome of interest is startup failure. Columns 1-2 limit the sample to investor pairs involving female investors. We estimate a statistically insignificant coefficient on the same gender indicator in this case. Thus, though the sample is small, there does not appear to be any evidence that female investors have a lower bar for female-led companies due to non-financial motivations.

Column (3) instead limits the sample to pairs involving male investors. In this case we estimate a significant positive coefficient on the same gender indicator, meaning that the male-led startups that male investors reach out to are actually more likely to fail than the female-led startups they reach out to. Column (4) shows similar results with investor fixed effects. Thus, the evidence is also inconsistent with the view that male investors have strictly financial motivations for favoring male founders. Panel B of Table 10 repeats the same analysis using an IPO/Acquisition indicator variable as a measure of success. We find qualitatively similar results in this case. Male-male pairs underperform male-female pairs, even within-investor. There is no statistically significant difference between female-female pairs and female-male pairs.

These findings more generally reinforce our previous findings that male investors do not appear to favor male founders due to unobservable startup quality, or within-gender screening/monitoring advantages stemming from sector expertise. Under either of those hypotheses, male-male pairs should outperform male-female pairs. The fact that male-female pairs outperform instead would seem to suggest male investors are reluctant to reach out to startups led by female founders for taste reasons, and therefore only do so for the most promising companies.

\footnotetext{
${ }^{19}$ We thank Shai Bernstein for sharing code to compute this measure.
} 


\subsection{Discussion}

In previous section, we have attempted to explore the most likely explanations for our baseline results that involve male investors having purely financial motives for favoring male-led startups over observably similar female-led startups. Overall, the evidence does not seem consistent with these explanations. Rather, the evidence appears more consistent with some form of taste-based discrimination. We define taste-based discrimination broadly to include outright sexism (explicit or implicit), as well as more subtle things, such as a desire by male investors to mentor founders who remind them of themselves. We also want to be careful not to completely rule out the possibility that female investors prefer to invest in female founders for taste-based reasons as well. That is, it is possible that male and female investors exhibit symmetric homophilistic preferences with respect to gender. The findings in the previous section - that female-female pairs do no underperform femalemale pairs - would seem inconsistent with symmetric homophilistic preferences. However, given the small sample size available to us for that test, we may find no significant performance difference only because we lack statistical power in the female investor sample. Yet, even if male and female investors have symmetric taste-based motivations for preferring to invest within-gender, such tastebased motivations are of greater concern for female founders, as the bulk of early stage investors are male. Thus, in either case, one implication of our results would be that more female investors are likely to be necessary to support the entry of more female entrepreneurs.

Moreover, that same implication would also follow, even if - contrary to our findings in Section 4.3 - our baseline results were driven by within-gender screening/monitoring advantages. That is, even if investors symmetrically prefer to invest within gender do to a screening/monitoring advantage arising from sector specialization (or any other source), our results would still suggest that more female investors are likely to be necessary to support the entry of more female entrepreneurs. In that case, it would be because female investors are better suited to pick the best female-led startups to invest in, or else are better suited to add value to female-led companies after making an investment.

More generally, while our data allow us to make significant progress toward disentangling var- 
ious forms of taste-based and statistical discrimination, we think that even absent the ability to disentangle them, this paper makes a significant contribution. Any debate about statistical versus taste-based discrimination begins from the premise that there is differential treatment in the first place. However, up until this point, most evidence of differential treatment in the entrepreneurship setting has been indirect at best, due to the fact that most datasets only cover startups that successfully raise capital. We find credible evidence, based on a large sample of fundraising startups, that female-led startups have more difficulty garnering interest and raising capital from male investors compared to observably similar male-led startups.

\section{Conclusion}

In this paper, we examine whether male investors are biased against female entrepreneurs. To do so, we use a unique dataset obtained from AngelList, which allows us to observe detailed investorfounder interactions for a large sample of fundraising startups, some of which succeed in raising capital and some of which fail. We find that female founders are significantly less successful garnering interest and raising capital from male investors compared to observably similar male founders. In contrast, the same female founders are actually more successful than male founders with female investors. The results do not appear to be driven by differences across founder gender in startup quality, sector focus, or risk. They also do not appear to be driven by differences in the motives of male and female investors. Overall, our findings are most consistent with either (1) taste-based discrimination by male investors and no gender discrimination by female-investors or (2) taste-based discrimination by both male and female investors in favor of their own gender.

In either case, given that the bulk of investors are male, our results suggest that an increase in female investors is likely necessary to support an increase in female entrepreneurship. The results nicely complement those of Gompers and Wang (2017a) who find that gender diversity in venture capital firms has important effects on investment choice and outcomes. However, given that early stage investors are often drawn from the pool of former entrepreneurs, which at this point is mostly 
male, the above conclusion gives rise to a "chicken and egg" problem. Thus, one implication of our findings is that policies like the JOBS Act, which promote the democratization of capital by facilitating various forms of equity crowdfunding, may be key to changing the existing equilibrium. 


\section{References}

Bailey, Michael C., Rachel Cao, Theresa Kuchler, and Johannes Stroebel, 2017, The economic effects of social networks: Evidence from the housing market, Journal of Political Economy Forthcoming.

Bernstein, Shai, Arthur Korteweg, and Kevin Laws, 2017, Attracting early-stage investors: Evidence from a randomized field experiment, Journal of Finance 72, 509-538.

Bertrand, Marianne and Sendhil Mullainathan, 2004, Are Emily and Greg more employable than Lakisha and Jamal? A field experiment on labor market discrimination, American Economic Review 94, 991-1013.

Bonin, Holger, Thomas Dohmen, Armin Falk, David Huffman, and Uwe Sunde, 2007, Cross-sectional earnings risk and occupational sorting: The role of risk attitudes, Labour Economics 14, 926-937.

Brooks, Alison Wood, Laura Huang, Sarah Wood Kearney, and Fiona E Murray, 2014, Investors prefer entrepreneurial ventures pitched by attractive men, Proceedings of the National Academy of Sciences 111, 4427-4431.

Brush, Candida, Patricia G Greene, Lakshmi Balachandra, and Amy E Davis, 2014, Diana report: Women entrepreneurs 2014-bridging the gender gap in venture capital, Arthur M. Blank Center for Entrepreneurship Babson College .

Coleman, Susan and Alicia Robb, 2009, A comparison of new firm financing by gender: Evidence from the Kauffman firm survey data, Small Business Economics 33, 397-411.

Coleman, Susan and Alicia Robb, 2016, The Next Wave: Financing Women's Growth-Oriented Firms (Stanford University Press).

Croson, Rachel and Uri Gneezy, 2009, Gender differences in preferences, Journal of Economic Literature 47, 448-474.

Fisman, Raymond, Daniel Paravisini, and Vikrant Vig, 2017, Cultural proximity and loan outcomes, The American Economic Review 107, 457-492.

Gompers, Paul A, Vladimir Mukharlyamov, Emily Weisburst, and Yuhai Xuan, 2014, Gender effects in venture capital, Working paper (Harvard University).

Gompers, Paul A and Sophie Q Wang, 2017a, And the children shall lead: Gender diversity and performance in venture capital, Working paper .

Gompers, Paul A and Sophie Q Wang, 2017b, Diversity in innovation, Working Paper (Harvard University).

Greenberg, Jason and Ethan Mollick, 2017, Activist choice homophily and the crowdfunding of female founders, Administrative Science Quarterly 62, 341-374.

Marianne, Bertrand, 2011, New perspectives on gender, Handbook of labor economics 4, 1543-1590.

Marom, Dan, Alicia Robb, and Orly Sade, 2016, Gender dynamics in crowdfunding (Kickstarter):

Evidence on entrepreneurs, investors, deals and taste-based discrimination, Working Paper (Hebrew University of Jerusalem). 
Raina, Sahil, 2017, VC financing and the entrepreneurship gender gap, Working Paper (University of Alberta).

Tracy, Spencer L, 2011, Accelerating job creation in America: The promise of high-impact companies, SBA Office of Advocacy, Washington . 


\section{Figures and Tables}

Table 1: Gender distribution on AngelList, Crunchbase and VentureSource

Notes: The table reports the percent of women in entrepreneurial firm founder positions or as investors in three databases. The AngelList sample includes the startups and investors active on the platform starting in late 2009. Startups are those that sought capital publicly on the website. Crunchbase is a wiki-style website of startups, investors and exits maintained since 2010. VentureSource is a database of venture capital financings and investors provided by VentureSource. Gender of both founders and investors was identified using the algorithm and manual assignment detailed in Section 3.3. Crunchbase numbers for founders are for firms founded between 2010 and the present and headquartered in the U.S.. The VentureSource founder statistics are for firms founded between 2010-2015. The VentureSource investor statistics report the fraction of board members of firms financed between 2010-present that are women.

\begin{tabular}{l|ccc}
\hline & AngelList & Crunchbase & VentureSource \\
\hline \% firms with female CEO/founders & $15.8 \%$ & $13 \%$ & $11 \%$ \\
\% firms with any female founder & $20.9 \%$ & $13.4 \%$ & $17.3 \%$ \\
$\%$ female investors & $8 \%$ & $5 \%$ & $6.5 \%$ \\
\hline \hline
\end{tabular}




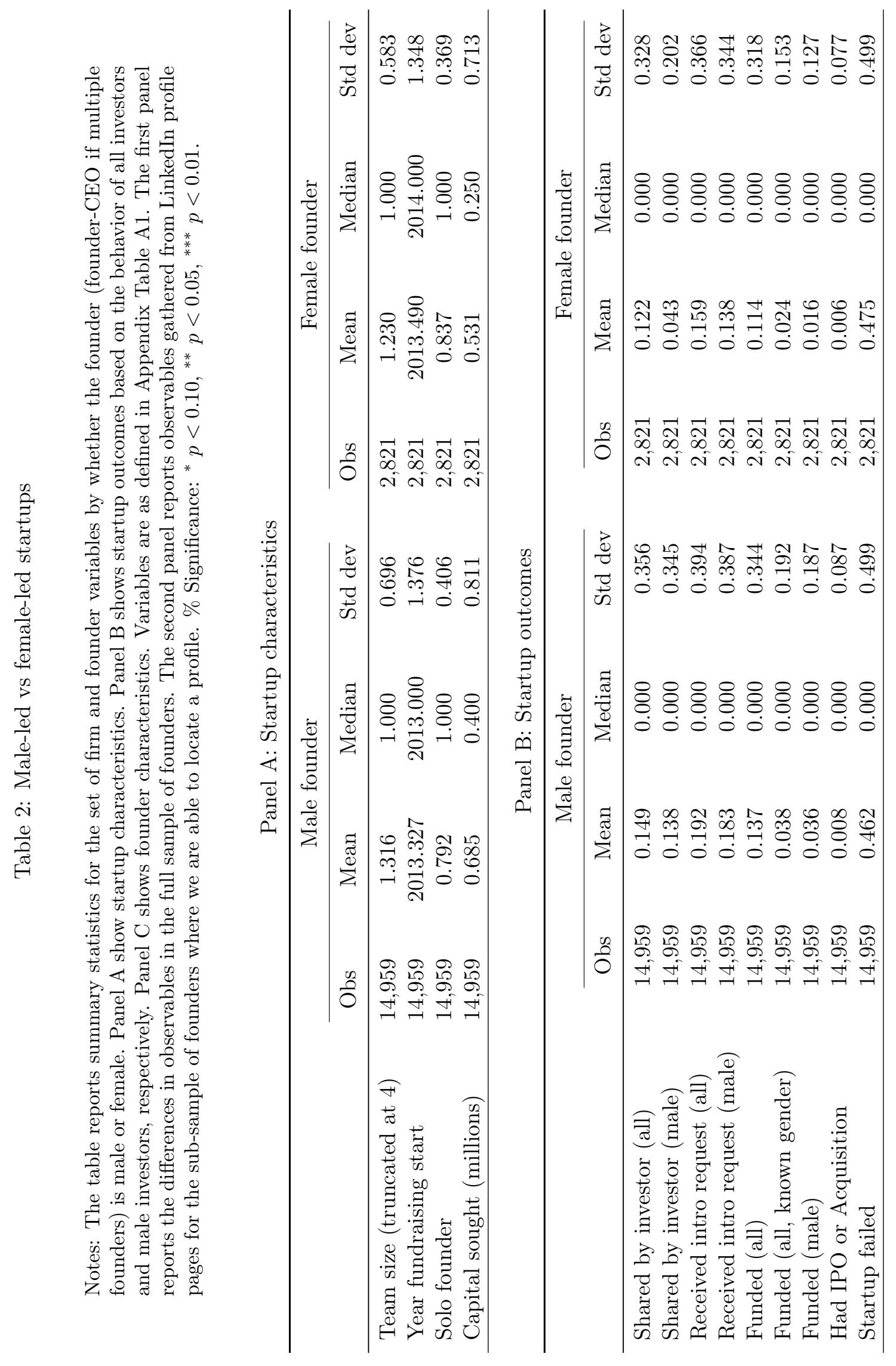




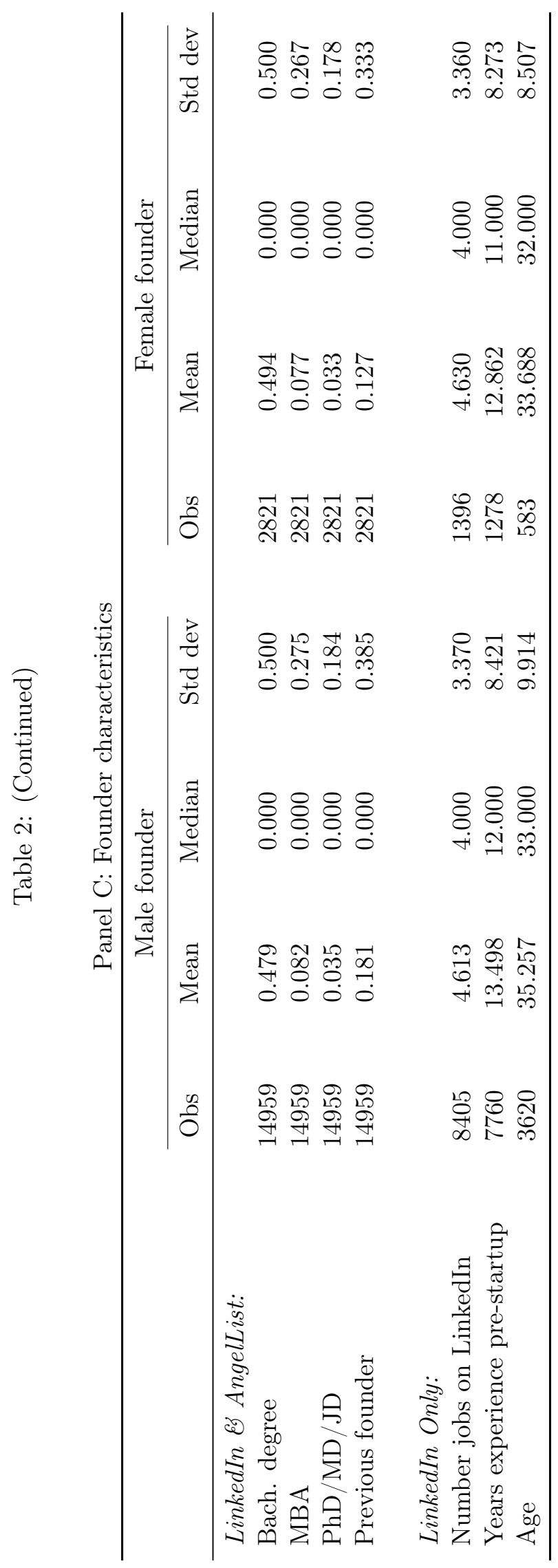


Table 3: Differences in female and male investors with at least one introduction

Notes: The table reports summary statistics for male and female investors - who have made at least one introduction - where we can identify the LinkedIn data. All variables measured as of June 2017 and defined in Table 2. "Previous founder" is defined only for individuals that have at least one listed position on their LinkedIn profile.

\begin{tabular}{|c|c|c|c|c|c|c|c|c|}
\hline & \multicolumn{4}{|c|}{ Male investor } & \multicolumn{4}{|c|}{ Female investors } \\
\hline & Obs & Mean & Median & Std dev & Obs & Mean & Median & Std dev \\
\hline Bach. degree & 3607 & 0.95 & 1.00 & 0.22 & 278 & 0.97 & 1.00 & 0.18 \\
\hline MBA & 3607 & 0.24 & 0.00 & 0.43 & 278 & 0.24 & 0.00 & 0.43 \\
\hline $\mathrm{PhD} / \mathrm{MD} / \mathrm{JD}$ & 3607 & 0.08 & 0.00 & 0.26 & 278 & 0.10 & 0.00 & 0.30 \\
\hline Previous founder & 3774 & 0.57 & 1.00 & 0.49 & 298 & 0.52 & 1.00 & 0.50 \\
\hline Number jobs on LinkedIn & 3774 & 4.71 & 5.00 & 1.11 & 298 & 5.04 & 5.00 & 1.99 \\
\hline Age & 3123 & 40.32 & 39.00 & 9.71 & 219 & 38.21 & 37.00 & 9.33 \\
\hline Interest overlap & 2697 & 0.17 & 0.14 & 0.14 & 256 & 0.16 & 0.13 & 0.14 \\
\hline
\end{tabular}




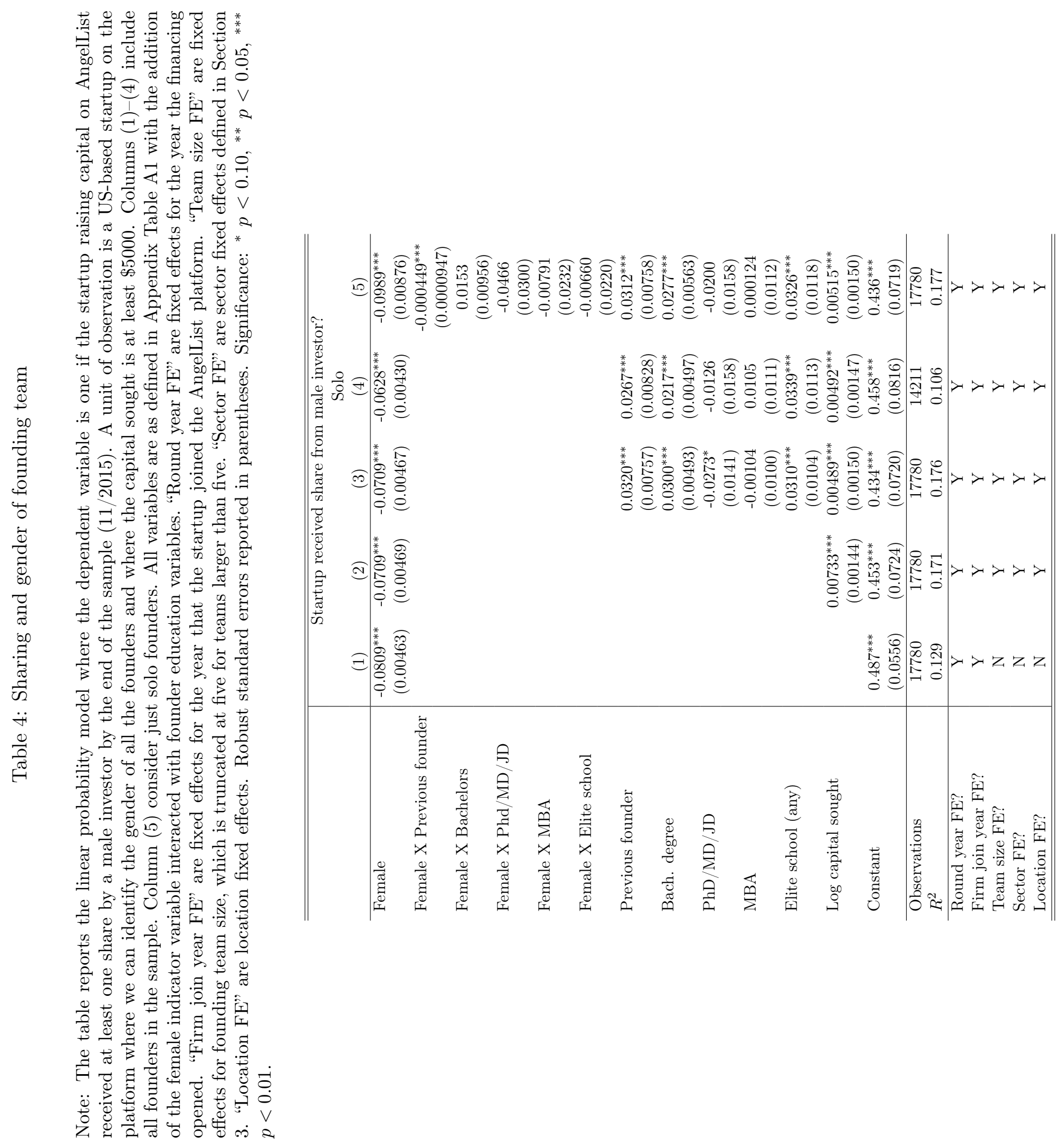




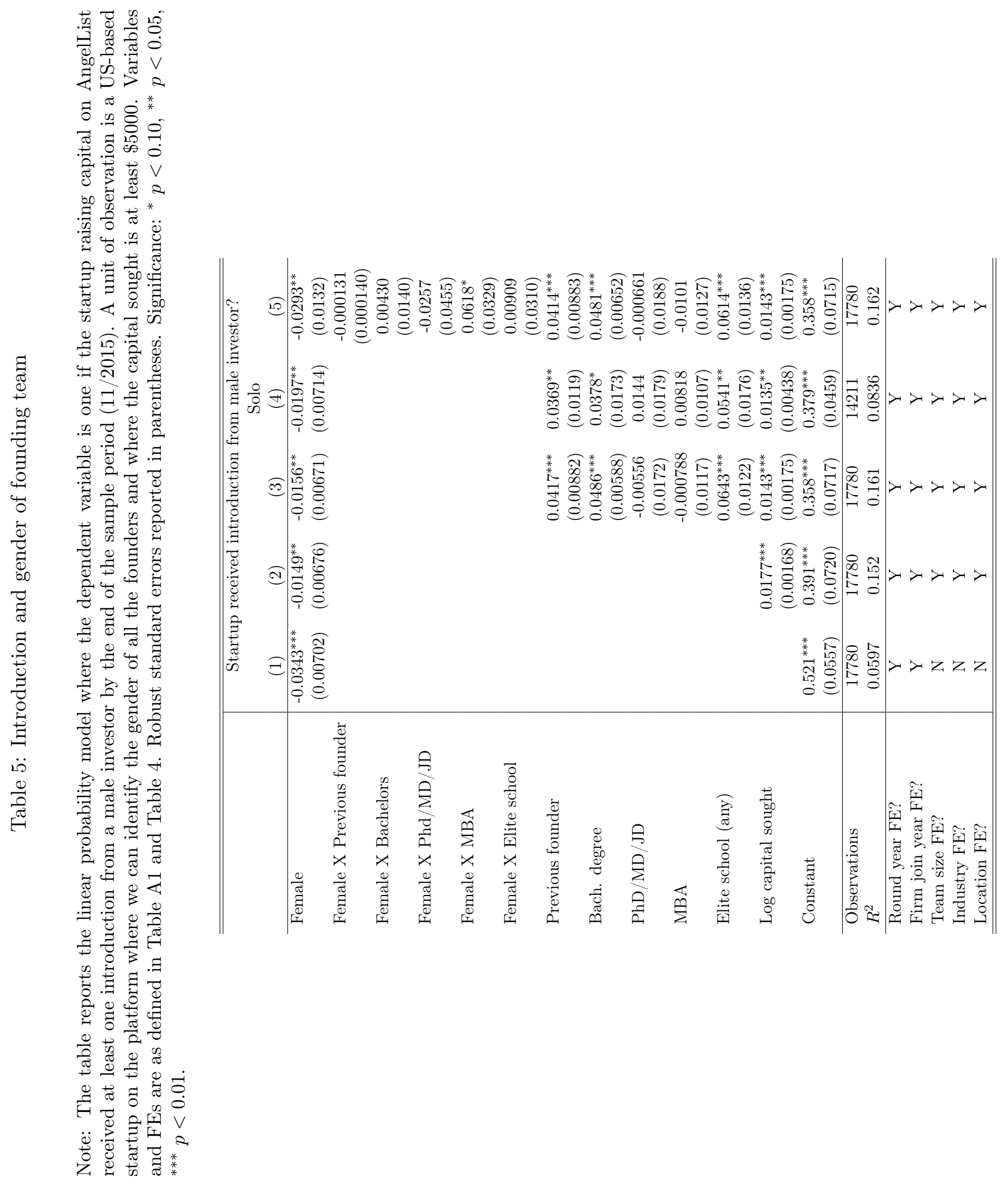




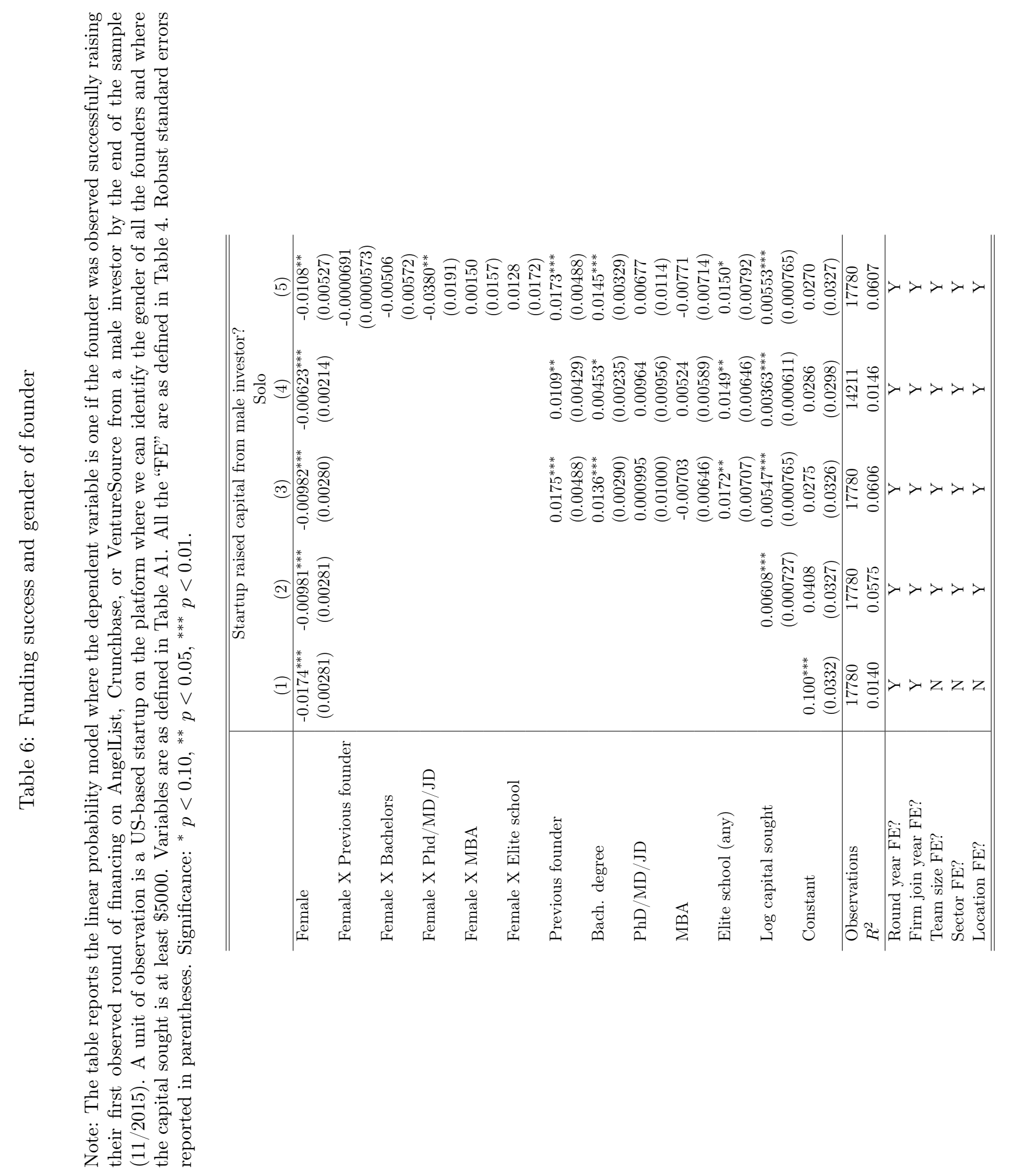


Table 7: Shares, introductions and funds raised from female and male investors

Note: The table repeats the analysis of Tables 4-6, with outcomes corresponding to female investors rather than male investors. A unit of observation is a US-based startup on the platform where we can identify the gender of all the founders and where the capital sought is at least \$5000. Variables are as defined in Table A1. All the "FE" are as defined in Table 4. Robust standard errors reported in parentheses. Significance: ${ }^{*} p<0.10,{ }^{* *} p<0.05,{ }^{* * *} p<0.01$.

\begin{tabular}{l|cc|cc|cc}
\hline \hline & \multicolumn{3}{|c}{$\begin{array}{c}\text { Female investor interest } \\
\text { Received share }\end{array}$} & \multicolumn{2}{c}{ Received intro. } & \multicolumn{2}{c}{ Raised round } \\
& $(1)$ & $(2)$ & $(3)$ & $(4)$ & $(5)$ & $(6)$ \\
\hline Female & $0.0757^{* * *}$ & $0.0783^{* * *}$ & $0.0128^{* * *}$ & $0.0204^{* * *}$ & $0.00682^{* * *}$ & $0.00855^{* * *}$ \\
& $(0.00531)$ & $(0.00534)$ & $(0.00420)$ & $(0.00418)$ & $(0.00227)$ & $(0.00227)$ \\
Previous founder & & $0.0112^{* * *}$ & & $0.0197^{* * *}$ & & $0.00465^{*}$ \\
& & $(0.00407)$ & & $(0.00510)$ & & $(0.00250)$ \\
Bach. degree & & $0.00730^{* * *}$ & & $0.0123^{* * *}$ & & -0.000207 \\
& & $(0.00252)$ & & $(0.00308)$ & & $(0.00145)$ \\
PhD/MD/JD & & 0.00948 & & 0.00128 & & -0.00454 \\
& & $(0.00854)$ & & $(0.0105)$ & & $(0.00430)$ \\
MBA & & -0.00368 & & -0.00566 & & -0.00139 \\
& & $(0.00509)$ & & $(0.00678)$ & & $(0.00317)$ \\
Elite school (any) & & -0.000387 & & $0.0229^{* * *}$ & & 0.00450 \\
& & $(0.00524)$ & & $(0.00747)$ & & $(0.00347)$ \\
Log capital sought & & 0.000500 & & $0.00528^{* * *}$ & & $0.00149^{* * *}$ \\
& & $(0.000744)$ & & $(0.000803)$ & & $(0.000425)$ \\
Constant & $0.0685^{* *}$ & 0.0567 & $0.221^{* * *}$ & $0.155^{* * *}$ & 0.0242 & 0.00536 \\
& $(0.0286)$ & $(0.0403)$ & $(0.0462)$ & $(0.0494)$ & $(0.0171)$ & $(0.0166)$ \\
\hline Observations & 17780 & 17780 & 17780 & 17780 & 17780 & 17780 \\
$R^{2}$ & 0.0531 & 0.0684 & 0.0192 & 0.0710 & 0.00383 & 0.0165 \\
\hline Round year FE? & $\mathrm{Y}$ & $\mathrm{Y}$ & $\mathrm{Y}$ & $\mathrm{Y}$ & $\mathrm{Y}$ & $\mathrm{Y}$ \\
Firm join year FE? & $\mathrm{Y}$ & $\mathrm{Y}$ & $\mathrm{Y}$ & $\mathrm{Y}$ & $\mathrm{Y}$ & $\mathrm{Y}$ \\
Team size FE? & $\mathrm{N}$ & $\mathrm{Y}$ & $\mathrm{N}$ & $\mathrm{Y}$ & $\mathrm{N}$ & $\mathrm{Y}$ \\
Sector FE? & $\mathrm{N}$ & $\mathrm{Y}$ & $\mathrm{N}$ & $\mathrm{Y}$ & $\mathrm{N}$ & $\mathrm{Y}$ \\
Location FE? & $\mathrm{N}$ & $\mathrm{Y}$ & $\mathrm{N}$ & $\mathrm{Y}$ & $\mathrm{N}$ & $\mathrm{Y}$ \\
\hline \hline
\end{tabular}


Table 8: Shares, intros and funds raised from female and male investors: Sector differences and robustness

Note: The table repeats the estimation from Tables 4-7 for sub-samples of entrepreneurial firms split by sector classification or alternative fixed effect specifications. Panel A presents the subset of firms excluding those with tags that are either predominantly women or predominantly men. Here, predominantly female tags are tags where more than $32 \%$ (twice as large as population percentage) of firms with that tag are female-founded. Predominantly male tags are those with less than half of the female percentage $(8 \%)$. Panel B presents the main specification where the sector fixed effects are replaced by tag combination fixed effects based on the combination of sector tags listed on a startup's AngelList profile. Startups can have more than one tag. Panel $\mathrm{C}$ excludes startups where there was consensus in an online survey showing the company's description that it was a gender-neutral firm. All regressions include the controls found in Table 7 with the exception of Panel B that replaces sector FE with tag FE. Robust standard errors reported in parentheses. Significance: ${ }^{*} p<0.10,{ }^{* *} p<0.05,{ }^{* * *} p<0.01$.

\begin{tabular}{|c|c|c|c|c|c|c|}
\hline & \multicolumn{6}{|c|}{ Panel A: Excluding startups with gender-dominant tags } \\
\hline & \multicolumn{2}{|c|}{ Received share } & \multicolumn{2}{|c|}{ Received intro. } & \multicolumn{2}{|c|}{ Received capital } \\
\hline & $\begin{array}{c}\text { Female } \\
(1)\end{array}$ & $\begin{array}{c}\text { Male } \\
(2)\end{array}$ & $\begin{array}{c}\text { Female } \\
(3)\end{array}$ & $\begin{array}{c}\text { Male } \\
(4)\end{array}$ & $\begin{array}{c}\text { Female } \\
(5)\end{array}$ & $\begin{array}{c}\text { Male } \\
(6)\end{array}$ \\
\hline \multirow[t]{2}{*}{ Female } & $0.0781^{* * *}$ & $-0.0640^{* * *}$ & $0.0177^{* * *}$ & $-0.0192^{* *}$ & $0.00709^{* *}$ & $-0.0102^{* * *}$ \\
\hline & $(0.00691)$ & $(0.00585)$ & $(0.00516)$ & $(0.00840)$ & $(0.00285)$ & $(0.00351)$ \\
\hline Observations & 11175 & 11175 & 11175 & 11175 & 11175 & 11175 \\
\hline$R^{2}$ & 0.0648 & 0.167 & 0.0626 & 0.152 & 0.0166 & 0.0563 \\
\hline \multirow[t]{4}{*}{ Mean dep. var. } & 0.0222 & 0.115 & 0.0336 & 0.165 & 0.00770 & 0.0304 \\
\hline & \multicolumn{6}{|c|}{ Panel B: Inclusion of sector tags as controls } \\
\hline & \multicolumn{2}{|c|}{ Received share } & \multicolumn{2}{|c|}{ Received intro. } & \multicolumn{2}{|c|}{ Received capital } \\
\hline & $\begin{array}{c}\text { Female } \\
(1)\end{array}$ & $\begin{array}{c}\text { Male } \\
(2)\end{array}$ & $\begin{array}{c}\text { Female } \\
(3)\end{array}$ & $\begin{array}{c}\text { Male } \\
(4)\end{array}$ & $\begin{array}{c}\text { Female } \\
(5)\end{array}$ & $\begin{array}{c}\text { Male } \\
(6)\end{array}$ \\
\hline Female & $0.0676^{* * *}$ & $-0.0662^{* * *}$ & $0.0230^{* * *}$ & $-0.0130^{*}$ & $0.00642^{* *}$ & $-0.0103^{* * *}$ \\
\hline & $(0.00554)$ & $(0.00554)$ & $(0.00473)$ & $(0.00762)$ & $(0.00266)$ & $(0.00376)$ \\
\hline Observations & 17063 & 17063 & 17063 & 17063 & 17063 & 17063 \\
\hline$R^{2}$ & 0.226 & 0.266 & 0.210 & 0.245 & 0.174 & 0.184 \\
\hline Founders & 16706 & 16706 & 16706 & 16706 & 16706 & 16706 \\
\hline \multirow[t]{4}{*}{ Mean dep. var. } & 0.0253 & 0.125 & 0.0394 & 0.180 & 0.00873 & 0.0404 \\
\hline & \multicolumn{6}{|c|}{ Panel C: Manually categorized gender neutral startups } \\
\hline & \multicolumn{2}{|c|}{ Received share } & \multicolumn{2}{|c|}{ Received intro. } & \multicolumn{2}{|c|}{ Received capital } \\
\hline & $\begin{array}{c}\text { Female } \\
\text { (1) }\end{array}$ & $\begin{array}{c}\text { Male } \\
(2)\end{array}$ & $\begin{array}{c}\text { Female } \\
(3)\end{array}$ & $\begin{array}{c}\text { Male } \\
(4)\end{array}$ & $\begin{array}{c}\text { Female } \\
(5)\end{array}$ & $\begin{array}{c}\text { Male } \\
(6)\end{array}$ \\
\hline Female & $\begin{array}{c}0.0680^{* * *} \\
(0.0112)\end{array}$ & $\begin{array}{c}-0.0746^{* * *} \\
(0.0104)\end{array}$ & $\begin{array}{c}0.0214^{* *} \\
(0.00962)\end{array}$ & $\begin{array}{c}-0.0323^{* *} \\
(0.0142)\end{array}$ & $\begin{array}{c}0.00483 \\
(0.00471)\end{array}$ & $\begin{array}{c}-0.0121^{*} \\
(0.00653)\end{array}$ \\
\hline Observations & 4330 & 4330 & 4330 & 4330 & 4330 & 4330 \\
\hline$R^{2}$ & 0.0556 & 0.184 & 0.0728 & 0.166 & 0.0148 & 0.0616 \\
\hline Controls? & $\mathrm{Y}$ & $\overline{\mathrm{Y}}$ & $\mathrm{Y}$ & Y Y & $\mathrm{Y}$ & $\mathrm{Y}$ \\
\hline FE? & Y & $\mathrm{Y}$ & $\mathrm{Y}$ & Y & $\mathrm{Y}$ & $\mathrm{Y}$ \\
\hline
\end{tabular}


Table 9: Relationship between male and female investor interest

Notes: This table reports the linear probability estimates of male investor interest for startups by each founder gender. Panel A considers the set of male founders and Panel B considers the set of female founders. The variable of interest "Had female inv. interest" is equal to one if the startup received at least one share, introduction request, or investment round from a female investor, respectively. A unit of observation is a US-based startup on the platform where we can identify the gender of all the founders and where the capital sought is at least $\$ 5000$. Variables and fixed effects are as defined in Table 4. "FE" include, round year, firm join year, team size, sector and location fixed effects. Robust standard errors reported in parentheses. Significance: ${ }^{*} p<0.10,{ }^{* *} p<0.05,{ }^{* * *} p<0.01$.

\begin{tabular}{|c|c|c|c|}
\hline & \multicolumn{3}{|c|}{$\begin{array}{c}\text { Panel A: Male founders } \\
\text { Received from a male investor: }\end{array}$} \\
\hline & $\begin{array}{c}\text { Share } \\
\text { (1) }\end{array}$ & $\begin{array}{c}\text { Intro } \\
(2)\end{array}$ & $\begin{array}{c}\text { Funding } \\
(3)\end{array}$ \\
\hline \multirow[t]{2}{*}{ Had female inv. interest } & $0.313^{* * *}$ & $0.461^{* * *}$ & $0.151^{* * *}$ \\
\hline & $(0.0184)$ & $(0.0170)$ & $(0.0161)$ \\
\hline \multirow[t]{2}{*}{ Previous founder } & $0.0260^{* * *}$ & $0.0303^{* * *}$ & $0.0127^{* *}$ \\
\hline & $(0.00818)$ & $(0.00919)$ & $(0.00524)$ \\
\hline \multirow[t]{2}{*}{ Bach. degree } & $0.0269^{* * *}$ & $0.0434^{* * *}$ & $0.0129^{* * *}$ \\
\hline & $(0.00555)$ & $(0.00634)$ & $(0.00325)$ \\
\hline \multirow[t]{2}{*}{$\mathrm{PhD} / \mathrm{MD} / \mathrm{JD}$} & $-0.0273^{*}$ & -0.00745 & 0.00323 \\
\hline & $(0.0154)$ & $(0.0178)$ & $(0.0112)$ \\
\hline \multirow[t]{2}{*}{ MBA } & 0.00239 & -0.00173 & -0.00561 \\
\hline & $(0.0109)$ & $(0.0123)$ & $(0.00706)$ \\
\hline \multirow[t]{2}{*}{ Elite school (any) } & $0.0248^{* *}$ & $0.0527^{* * *}$ & 0.0113 \\
\hline & $(0.0114)$ & $(0.0132)$ & $(0.00785)$ \\
\hline \multirow[t]{2}{*}{ Log capital sought } & $0.00447^{* * *}$ & $0.0107^{* * *}$ & $0.00534^{* * *}$ \\
\hline & $(0.00172)$ & $(0.00193)$ & $(0.000873)$ \\
\hline Observations & 14959 & 14959 & 14959 \\
\hline$R^{2}$ & 0.211 & 0.212 & 0.0861 \\
\hline \multirow[t]{3}{*}{ Mean dep. var. } & 0.138 & 0.183 & 0.0363 \\
\hline & Panel & 3: Female fo & unders \\
\hline & Share & Intro & Funding \\
\hline \multirow[t]{2}{*}{ Had female inv. interest } & $0.107^{* * *}$ & $0.259^{* * *}$ & $0.0524^{* * *}$ \\
\hline & $(0.0201)$ & $(0.0272)$ & $(0.0127)$ \\
\hline \multirow[t]{2}{*}{ Previous founder } & 0.00543 & 0.0247 & $0.0196^{*}$ \\
\hline & $(0.0144)$ & $(0.0224)$ & $(0.0114)$ \\
\hline \multirow[t]{2}{*}{ Bach. degree } & $0.0186^{* *}$ & $0.0391^{* * *}$ & 0.00587 \\
\hline & $(0.00754)$ & $(0.0128)$ & $(0.00498)$ \\
\hline \multirow[t]{2}{*}{$\mathrm{PhD} / \mathrm{MD} / \mathrm{JD}$} & -0.0387 & -0.0209 & -0.0238 \\
\hline & $(0.0247)$ & $(0.0403)$ & $(0.0161)$ \\
\hline \multirow[t]{2}{*}{ MBA } & 0.0158 & 0.0374 & -0.00459 \\
\hline & $(0.0199)$ & $(0.0291)$ & $(0.0138)$ \\
\hline \multirow[t]{2}{*}{ Elite school (any) } & $0.0391^{* *}$ & $0.0661^{* *}$ & $0.0320^{* *}$ \\
\hline & $(0.0185)$ & $(0.0275)$ & $(0.0147)$ \\
\hline \multirow[t]{2}{*}{ Log capital sought } & 0.00355 & $0.0204^{* * *}$ & $0.00365^{* * *}$ \\
\hline & $(0.00217)$ & $(0.00364)$ & $(0.00128)$ \\
\hline Observations & 2821 & 2821 & 2821 \\
\hline$R^{2}$ & 0.130 & 0.233 & 0.0710 \\
\hline Mean dep. var. & 0.0425 & 0.138 & 0.0163 \\
\hline $\mathrm{FE} ?$ & $\mathrm{Y}$ & $\mathrm{Y}$ & $\mathrm{Y}$ \\
\hline
\end{tabular}


Table 10: Differences in outcomes by investor gender: introductions

Notes: The table reports linear probability model estimates for the dependent variables defined in Table A1. Here a unit of observation is a pair: investor requesting an introduction and startup founder. That is, for each observed introduction, the variable "Same gender" is equal to one if the founder and investor have the same gender. Columns (1) and (2) in each panel considers the set of female investors, while (3) and (4) show the results for men. Each panel uses the dependent variables measuring startup success as defined in Table A1. The even columns include investor fixed effects. Controls (not reported) include fixed effects for year, sector, and team size along with controls for capital sought, serial founder and the pairwise "interest overlap" defined in Table A1. Robust standard errors clustered at the investor level are reported in parentheses. Significance: ${ }^{*} p<0.10,{ }^{* *} p<0.05,{ }^{* * *} p<0.01$.

\begin{tabular}{|c|c|c|c|c|}
\hline & \multicolumn{4}{|c|}{$\begin{array}{l}\text { Panel A: Startup failed } \\
\text { Investor gender }\end{array}$} \\
\hline & $\begin{array}{c}\text { Female } \\
(1)\end{array}$ & $\begin{array}{c}\text { Female } \\
(2)\end{array}$ & $\begin{array}{c}\text { Male } \\
(3)\end{array}$ & $\begin{array}{l}\text { Male } \\
(4)\end{array}$ \\
\hline Same gender & $\begin{array}{l}0.001000 \\
(0.0434)\end{array}$ & $\begin{array}{l}-0.00915 \\
(0.0548)\end{array}$ & $\begin{array}{c}0.0640^{* * *} \\
(0.0124)\end{array}$ & $\begin{array}{l}0.0693^{* * *} \\
(0.0151)\end{array}$ \\
\hline Interest overlap & $\begin{array}{l}0.0158 \\
(0.130)\end{array}$ & $\begin{array}{c}-0.0694 \\
(0.183)\end{array}$ & $\begin{array}{c}0.0176 \\
(0.0359)\end{array}$ & $\begin{array}{c}0.0159 \\
(0.0495)\end{array}$ \\
\hline Constant & $\begin{array}{c}0.305 \\
(0.490)\end{array}$ & $\begin{array}{c}0.540 \\
(0.516)\end{array}$ & $\begin{array}{l}0.254^{*} \\
(0.144)\end{array}$ & $\begin{array}{c}0.180 \\
(0.191)\end{array}$ \\
\hline $\begin{array}{l}\text { Observations } \\
R^{2}\end{array}$ & $\begin{array}{c}792 \\
0.0541\end{array}$ & $\begin{array}{c}792 \\
0.0476\end{array}$ & $\begin{array}{l}10887 \\
0.0837\end{array}$ & $\begin{array}{l}10887 \\
0.0799\end{array}$ \\
\hline & $\begin{array}{c}\text { Par } \\
\text { Female } \\
(1)\end{array}$ & $\begin{array}{l}\text { el B: Start } \\
\text { Female } \\
(2)\end{array}$ & $\begin{array}{c}\text { ip had IPO } \\
\text { Male } \\
(3)\end{array}$ & $\begin{array}{l}\text { Acq. } \\
\text { Male } \\
(4)\end{array}$ \\
\hline Same gender & $\begin{array}{l}-0.00668 \\
(0.0254)\end{array}$ & $\begin{array}{l}0.00148 \\
(0.0316)\end{array}$ & $\begin{array}{c}-0.0301^{* * *} \\
(0.00745)\end{array}$ & $\begin{array}{l}-0.0171^{*} \\
(0.00894)\end{array}$ \\
\hline Interest overlap & $\begin{array}{c}0.0193 \\
(0.0763)\end{array}$ & $\begin{array}{r}-0.0981 \\
(0.106)\end{array}$ & $\begin{array}{c}0.0594^{* * *} \\
(0.0216)\end{array}$ & $\begin{array}{l}0.0494^{*} \\
(0.0294)\end{array}$ \\
\hline Constant & $\begin{array}{r}-0.0309 \\
(0.286)\end{array}$ & $\begin{array}{c}-0.00367 \\
(0.297)\end{array}$ & $\begin{array}{c}0.0810 \\
(0.0870)\end{array}$ & $\begin{array}{l}0.0952 \\
(0.114)\end{array}$ \\
\hline $\begin{array}{l}\text { Observations } \\
R^{2}\end{array}$ & $\begin{array}{c}792 \\
0.0524\end{array}$ & $\begin{array}{c}792 \\
0.0734\end{array}$ & $\begin{array}{l}10887 \\
0.0572\end{array}$ & $\begin{array}{l}10887 \\
0.0820\end{array}$ \\
\hline Investor FE? & $\mathrm{N}$ & $\mathrm{Y}$ & $\mathrm{N}$ & $\mathrm{Y}$ \\
\hline Year FE? & $\mathrm{Y}$ & $\mathrm{Y}$ & $\mathrm{Y}$ & $\mathrm{Y}$ \\
\hline Sector FE? & $\mathrm{Y}$ & $\mathrm{Y}$ & $\mathrm{Y}$ & $\mathrm{Y}$ \\
\hline Location FE? & $\mathrm{Y}$ & $\mathrm{Y}$ & $\mathrm{Y}$ & $\mathrm{Y}$ \\
\hline Team size FE? & $\mathrm{Y}$ & $\mathrm{Y}$ & $\mathrm{Y}$ & $\mathrm{Y}$ \\
\hline Controls? & $\mathrm{Y}$ & $\mathrm{Y}$ & $\mathrm{Y}$ & $\mathrm{Y}$ \\
\hline
\end{tabular}




\section{Appendix}

Table A1: Variable definitions

Notes: The table describes the main variables used throughout the analysis.

\begin{tabular}{|c|c|}
\hline Variable & Definition \\
\hline Received share & $\begin{array}{l}\text { An indicator equal to one if the startup received at least } \\
\text { one share from a male (female) investor on the AngelList } \\
\text { platform. A share allows an investor to point to a startup's } \\
\text { profile or fundraising activity to another user on the plat- } \\
\text { form. }\end{array}$ \\
\hline Received introduction & $\begin{array}{l}\text { An indicator equal to one if the startup received at least } \\
\text { one introduction from a male (female) investor on the An- } \\
\text { gelList platform. An introduction is a one-way inquiry by } \\
\text { investor to startup firm when the firm has an fundraising } \\
\text { event listed on their profile. Direct communication between } \\
\text { investor and startup is not possible on the platform without } \\
\text { reciprocal action by the startup firm. }\end{array}$ \\
\hline Funded & $\begin{array}{l}\text { An indicator equal to one if the startup was observed as } \\
\text { raising capital after their fundraising round on AngelList, } \\
\text { Crunchbase, SEC filings or VentureSource. }\end{array}$ \\
\hline Startup failed & $\begin{array}{l}\text { An indicator equal to one if the startup did not have any } \\
\text { online activity as of November } 2016 \text { that indicated the firm } \\
\text { was still active. A firm is active if their website does not } \\
\text { return and error and the returned page has some mention } \\
\text { of the startup's name. }\end{array}$ \\
\hline Had IPO or Acquisition & $\begin{array}{l}\text { An indicator equal to one if the startup firm had an initial } \\
\text { public offering or was acquired by November } 2016 \text {. Such } \\
\text { exits are observed in either Crunchbase or VentureSource. }\end{array}$ \\
\hline Team size & $\begin{array}{l}\text { The number of founders of the startup as listed in the } \\
\text { startup's AngelList profile. }\end{array}$ \\
\hline Year fundraised & The year the startup's fundraising first began on AngelList. \\
\hline Capital sought & $\begin{array}{l}\text { The original capital amount sought in the startup's first } \\
\text { fundraising campaign on AngelList. }\end{array}$ \\
\hline Serial founder & $\begin{array}{l}\text { An indicator equal to one if the startup founder's LinkedIn } \\
\text { profile indicated a past title as "founder" or "co-founder" at } \\
\text { a another firm prior to the founding of the current startup. }\end{array}$ \\
\hline Bachelors degree & $\begin{array}{l}\text { An indicator equal to one if the startup founder's LinkedIn } \\
\text { profile indicated that they received a bachelor's degree or } \\
\text { equivalent. Such information is also found in the short } \\
\text { founder biography on their AngelList profile and/or their } \\
\text { Crunchbase profile if available. }\end{array}$ \\
\hline $\mathrm{MD} / \mathrm{PhD} / \mathrm{JD}$ and MBA & $\begin{array}{l}\text { An indicator equal to one if the founder had a } \mathrm{PhD}, \mathrm{MD} \text { or } \\
\text { JD (MBA) in their AngelList or LinkedIn profile. }\end{array}$ \\
\hline Elite school (any) & $\begin{array}{l}\text { An indicator equal to one if any of the founder's pre-startup } \\
\text { degrees were from any of the following universities: MIT, } \\
\text { Princeton, UPenn, U. Chicago, Harvard, Yale, Caltech, } \\
\text { John Hopkins, Duke, Stanford, Yale, Columbia or North- } \\
\text { western. }\end{array}$ \\
\hline Years experience pre-startup & $\begin{array}{l}\text { A count of the number of years from the first observed } \\
\text { job date to the founding of the startup as available on the } \\
\text { founder's LinkedIn profile. }\end{array}$ \\
\hline Age & $\begin{array}{l}\text { The age in years of a startup founder as defined by the year } \\
\text { of their college graduation (minus 21) observed on their } \\
\text { LinkedIn profile or as reported directly on Crunchbase. }\end{array}$ \\
\hline Interest overlap & $\begin{array}{l}\text { The cosine similarity between the self-assigned tags of each } \\
\text { pair of investor and founder. }\end{array}$ \\
\hline
\end{tabular}


Table A2: Funding success and gender of founder: AngelList data only

Note: The table reports the linear probability model where the dependent variable is one if the founder was observed successfully raising their first observed round of financing on AngelList or VentureSource from a male investor by the end of the sample (11/2015). A unit of observation is a US-based startup on the platform where we can identify the gender of all the founders and where the capital sought is at least $\$ 5000$. The funding dependent variable is one if the startup raised capital from an investor that is also an active AngelList user. Variables are as defined in Table A1. All the "FE" are as defined in Table 4. Robust standard errors reported in parentheses. Significance: ${ }^{*} p<0.10,{ }^{* *} p<0.05,{ }^{* * *} p<0.01$.

\begin{tabular}{|c|c|c|c|c|c|}
\hline & \multicolumn{5}{|c|}{ Startup raised capital from male investor? } \\
\hline & (1) & $(2)$ & (3) & $\begin{array}{c}(4) \\
\text { Solo }\end{array}$ & (5) \\
\hline Female & $\begin{array}{c}-0.0128^{* * *} \\
(0.00230)\end{array}$ & $\begin{array}{c}-0.00827^{* * *} \\
(0.00232)\end{array}$ & $\begin{array}{c}-0.00823^{* * *} \\
(0.00231)\end{array}$ & $\begin{array}{c}-0.00585^{* * *} \\
(0.00178)\end{array}$ & $\begin{array}{c}-0.00877^{* *} \\
(0.00437)\end{array}$ \\
\hline Female X Previous founder & & & & & $\begin{array}{c}-0.0000402 \\
(0.0000468)\end{array}$ \\
\hline Female X Bachelors & & & & & $\begin{array}{l}-0.00385 \\
(0.00467)\end{array}$ \\
\hline Female X Phd/MD/JD & & & & & $\begin{array}{c}-0.0259^{*} \\
(0.0150)\end{array}$ \\
\hline Female X MBA & & & & & $\begin{array}{l}-0.00259 \\
(0.0128)\end{array}$ \\
\hline Female X Elite school & & & & & $\begin{array}{c}0.0174 \\
(0.0146)\end{array}$ \\
\hline Previous founder & & & $\begin{array}{c}0.00895^{* *} \\
(0.00406)\end{array}$ & $\begin{array}{c}0.00405 \\
(0.00359)\end{array}$ & $\begin{array}{l}0.00880^{* *} \\
(0.00406)\end{array}$ \\
\hline Bach. degree & & & $\begin{array}{c}0.00746^{* * *} \\
(0.00249)\end{array}$ & $\begin{array}{c}0.00318 \\
(0.00202)\end{array}$ & $\begin{array}{c}0.00811^{* * *} \\
(0.00284)\end{array}$ \\
\hline $\mathrm{PhD} / \mathrm{MD} / \mathrm{JD}$ & & & $\begin{array}{l}-0.00173 \\
(0.00812)\end{array}$ & $\begin{array}{c}0.0115 \\
(0.00882)\end{array}$ & $\begin{array}{c}0.00221 \\
(0.00925)\end{array}$ \\
\hline MBA & & & $\begin{array}{l}-0.00404 \\
(0.00536)\end{array}$ & $\begin{array}{c}0.00527 \\
(0.00521)\end{array}$ & $\begin{array}{l}-0.00410 \\
(0.00595)\end{array}$ \\
\hline Elite school (any) & & & $\begin{array}{c}0.00700 \\
(0.00573)\end{array}$ & $\begin{array}{c}0.00955^{*} \\
(0.00553)\end{array}$ & $\begin{array}{c}0.00410 \\
(0.00634)\end{array}$ \\
\hline Log capital sought & & $\begin{array}{l}0.00310^{* * *} \\
(0.000614)\end{array}$ & $\begin{array}{l}0.00264^{* * *} \\
(0.000649)\end{array}$ & $\begin{array}{l}0.00227^{* * *} \\
(0.000520)\end{array}$ & $\begin{array}{l}0.00268^{* * *} \\
(0.000648)\end{array}$ \\
\hline Constant & $\begin{array}{c}0.0874^{* * *} \\
(0.0313) \\
\end{array}$ & $\begin{array}{c}0.0460 \\
(0.0307) \\
\end{array}$ & $\begin{array}{c}0.0402 \\
(0.0306) \\
\end{array}$ & $\begin{array}{c}0.0189 \\
(0.0249) \\
\end{array}$ & $\begin{array}{c}0.0398 \\
(0.0306) \\
\end{array}$ \\
\hline Observations & 17780 & 17780 & 17780 & 14211 & 17780 \\
\hline$R^{2}$ & 0.00955 & 0.0343 & 0.0354 & 0.00936 & 0.0354 \\
\hline Round year FE? & $\mathrm{Y}$ & $\mathrm{Y}$ & $\mathrm{Y}$ & $\mathrm{Y}$ & $\mathrm{Y}$ \\
\hline Firm join year FE? & Y & Y & Y & Y & Y \\
\hline Team size FE? & $\mathrm{N}$ & Y & Y & Y & Y \\
\hline Sector FE? & $\mathrm{N}$ & Y & Y & Y & $\mathrm{Y}$ \\
\hline Location FE? & $\mathrm{N}$ & Y & $\mathrm{Y}$ & $\mathrm{Y}$ & $\mathrm{Y}$ \\
\hline
\end{tabular}


Table A3: Additional controls

Notes: The table repeats the analysis found in Tables 4-6 with additional controls. The variable Total pre-startup jobs represents the total number of jobs the focal founder reported on LinkedIn prior to founding the startup, Years emp. experience represents the total number of years between the start year of the founder's first reported job on LinkedIn and the year of the AngelList fundraising campaign, Age represents the founder's imputed age (year of fundraising campaign - year of college graduation +22 ), Length of description represents the number of characters in the product description. Missing values of all variables are dummied out. A unit of observation is a US-based startup on the platform where we can identify the gender of all the founders and where the capital sought is at least $\$ 5000$. Variables are as defined in Table A1. All the "FE" are as defined in Table 4. Robust standard errors reported in parentheses. Significance: ${ }^{*} p<0.10,{ }^{* *} p<0.05,{ }^{* * *} p<0.01$.

\begin{tabular}{l|ccc}
\hline \hline & $\begin{array}{c}\text { Share } \\
(1)\end{array}$ & $\begin{array}{c}\text { Intro. } \\
(2)\end{array}$ & $\begin{array}{c}\text { Funded } \\
(3)\end{array}$ \\
\hline Female & $-0.0713^{* * *}$ & $-0.0154^{* *}$ & $-0.00979^{* * *}$ \\
& $(0.00469)$ & $(0.00670)$ & $(0.00280)$ \\
Log total pre-startup jobs & 0.00821 & $0.0319^{* * *}$ & 0.00784 \\
& $(0.00731)$ & $(0.00882)$ & $(0.00484)$ \\
Log years emp. experience & -0.00789 & $-0.0190^{* * *}$ & -0.00444 \\
& $(0.00556)$ & $(0.00684)$ & $(0.00330)$ \\
Age (yrs) & -0.000625 & $-0.00112^{*}$ & -0.000128 \\
& $(0.000588)$ & $(0.000668)$ & $(0.000352)$ \\
Log length of description & $0.0124^{* * *}$ & $0.00421^{* *}$ & $0.00414^{* * *}$ \\
& $(0.00154)$ & $(0.00207)$ & $(0.000787)$ \\
Constant & $0.420^{* * *}$ & $0.390^{* * *}$ & 0.0157 \\
& $(0.0761)$ & $(0.0776)$ & $(0.0357)$ \\
\hline Baseline Controls? & $\mathrm{Y}$ & $\mathrm{Y}$ & $\mathrm{Y}$ \\
Baseline FEs? & $\mathrm{Y}$ & $\mathrm{Y}$ & $\mathrm{Y}$ \\
\hline Observations & 17780 & 17780 & 17780 \\
$R^{2}$ & 0.179 & 0.164 & 0.0617 \\
\hline \hline
\end{tabular}


Table A4: Baseline results excluding consumer sectors

Notes: The table reports the regressions found in Table 7 after excluding startups in the consumer services and consumer products sectors. A unit of observation is a US-based startup on the platform where we can identify the gender of all the founders and where the capital sought is at least $\$ 5000$. Variables are as defined in Table A1. All the "FE" and "Controls" are as defined in Table 4. Robust standard errors reported in parentheses. Significance: ${ }^{*} p<0.10,{ }^{* *}$ $p<0.05,{ }^{* * *} p<0.01$.

\begin{tabular}{l|cc|cc|cc}
\hline \hline & \multicolumn{2}{|c}{ Received share } & \multicolumn{2}{c}{ Received intro. } & \multicolumn{2}{c}{ Received capital } \\
& Female & Male & Female & Male & Female & Male \\
& $(1)$ & $(2)$ & $(3)$ & $(4)$ & $(5)$ & $(6)$ \\
\hline Female & $0.0893^{* * *}$ & $-0.0854^{* * *}$ & $0.0182^{* *}$ & $-0.0244^{* *}$ & 0.00545 & $-0.0181^{* * *}$ \\
& $(0.00936)$ & $(0.00751)$ & $(0.00732)$ & $(0.0115)$ & $(0.00379)$ & $(0.00497)$ \\
\hline Observations & 8618 & 8618 & 8618 & 8618 & 8618 & 8618 \\
$R^{2}$ & 0.0750 & 0.190 & 0.0791 & 0.167 & 0.0150 & 0.0659 \\
\hline \hline Controls? & $\mathrm{Y}$ & $\mathrm{Y}$ & $\mathrm{Y}$ & $\mathrm{Y}$ & $\mathrm{Y}$ & $\mathrm{Y}$ \\
FE? & $\mathrm{Y}$ & $\mathrm{Y}$ & $\mathrm{Y}$ & $\mathrm{Y}$ & $\mathrm{Y}$ & $\mathrm{Y}$ \\
\hline \hline
\end{tabular}

Table A5: Gender neutral startups based on mean response

Notes: The table reports the regressions found in Table 7 after excluding startups where the average survey respondent labeled the firm as gender-neutral. A unit of observation is a US-based startup on the platform where we can identify the gender of all the founders and where the capital sought is at least $\$ 5000$. Variables are as defined in Table A1. All the "FE" and "Controls" are as defined in Table 4. Robust standard errors reported in parentheses. Significance: ${ }^{*} p<0.10,{ }^{* *} p<0.05,{ }^{* * *} p<0.01$.

\begin{tabular}{l|cc|cc|cc}
\hline \hline & \multicolumn{2}{|c}{ Received share } & \multicolumn{2}{c}{ Received intro. } & \multicolumn{2}{c}{ Received capital } \\
& Female & Male & Female & Male & Female & Male \\
& $(1)$ & $(2)$ & $(3)$ & $(4)$ & $(5)$ & $(6)$ \\
\hline Female & $0.0789^{* * *}$ & $-0.0686^{* * *}$ & $0.0216^{* * *}$ & $-0.0133^{*}$ & $0.00987^{* * *}$ & $-0.00856^{* *}$ \\
& $(0.00621)$ & $(0.00550)$ & $(0.00493)$ & $(0.00770)$ & $(0.00280)$ & $(0.00343)$ \\
\hline Observations & 14692 & 14692 & 14692 & 14692 & 14692 & 14692 \\
$R^{2}$ & 0.0663 & 0.185 & 0.0717 & 0.163 & 0.0160 & 0.0625 \\
\hline Controls? & $\mathrm{Y}$ & $\mathrm{Y}$ & $\mathrm{Y}$ & $\mathrm{Y}$ & $\mathrm{Y}$ & $\mathrm{Y}$ \\
FE? & $\mathrm{Y}$ & $\mathrm{Y}$ & $\mathrm{Y}$ & $\mathrm{Y}$ & $\mathrm{Y}$ & $\mathrm{Y}$ \\
\hline \hline
\end{tabular}


Table A6: Excluding social mission investors

Notes: The table repeats the analysis found in Tables 4-6. The sample here excludes all outcomes - shares, introductions or funding - made by investors on the AngelList platform identified as "social investors." These investors are Valor Ventures, Golden Seeds, Pipeline Angels, Built By Girls Ventures, BELLE Capital USA, Female Founders Fund, The Womens' Venture Capital Fund, Forerunner Ventures, 500 Women, Angel Academe, Phenomenelle Angels Fund, Broadway Angels, Topstone Angels, Plum Alley, The Jump Fund, Astia, Scale, Cross Culture Ventures, Gotham Gal Ventures, True Wealth Ventures, Halogen Ventures, Sofia Fund, Female Funders, Women Angels, Women Founders Network, Women Launch and Women Lead Inc. A unit of observation is a US-based startup on the platform where we can identify the gender of all the founders and where the capital sought is at least $\$ 5000$. Variables are as defined in Table A1. All the "FE" are as defined in Table 4 . Robust standard errors reported in parentheses. Significance:* $p<0.10,{ }^{* *} p<0.05,{ }^{* * *} p<0.01$.

\begin{tabular}{|c|c|c|c|c|c|c|}
\hline & \multicolumn{6}{|c|}{ Female investor interest, no social investors } \\
\hline & \multicolumn{2}{|c|}{ Received share } & \multicolumn{2}{|c|}{ Received intro. } & \multicolumn{2}{|c|}{ Raised round } \\
\hline & $(1)$ & $(2)$ & $(3)$ & $(4)$ & $(5)$ & $(6)$ \\
\hline Female & $0.0757^{* * *}$ & $0.0783^{* * *}$ & $0.0129^{* * *}$ & $0.0204^{* * *}$ & 0.00262 & $0.00378^{* *}$ \\
\hline & $(0.00531)$ & $(0.00534)$ & $(0.00420)$ & $(0.00418)$ & $(0.00168)$ & $(0.00170)$ \\
\hline Previous founder & & $0.0112^{* * *}$ & & $0.0191^{* * *}$ & & $0.00359^{*}$ \\
\hline & & $(0.00407)$ & & $(0.00509)$ & & $(0.00208)$ \\
\hline Bach. degree & & $0.00730^{* * *}$ & & $0.0121^{* * *}$ & & -0.000313 \\
\hline & & $(0.00252)$ & & $(0.00308)$ & & $(0.00120)$ \\
\hline $\mathrm{PhD} / \mathrm{MD} / \mathrm{JD}$ & & 0.00948 & & 0.00166 & & -0.00204 \\
\hline & & $(0.00854)$ & & $(0.0105)$ & & $(0.00354)$ \\
\hline $\mathrm{MBA}$ & & -0.00368 & & -0.00520 & & -0.000836 \\
\hline & & $(0.00509)$ & & $(0.00677)$ & & $(0.00256)$ \\
\hline Elite school (any) & & -0.000387 & & $0.0221^{* * *}$ & & 0.000276 \\
\hline & & $(0.00524)$ & & $(0.00744)$ & & $(0.00257)$ \\
\hline Log capital sought & & 0.000500 & & $0.00523^{* * *}$ & & 0.000563 \\
\hline & & $(0.000744)$ & & $(0.000802)$ & & $(0.000352)$ \\
\hline Constant & $0.0685^{* *}$ & 0.0567 & $0.221^{* * *}$ & $0.156^{* * *}$ & -0.000194 & $-0.0122^{* * *}$ \\
\hline & $(0.0286)$ & $(0.0403)$ & $(0.0462)$ & $(0.0494)$ & $(0.000146)$ & $(0.00238)$ \\
\hline Observations & 17780 & 17780 & 17780 & 17780 & 17780 & 17780 \\
\hline$R^{2}$ & 0.0531 & 0.0684 & 0.0192 & 0.0707 & 0.00163 & 0.00895 \\
\hline Round year FE? & $\mathrm{Y}$ & $\mathrm{Y}$ & $\mathrm{Y}$ & $\mathrm{Y}$ & $\mathrm{Y}$ & $\mathrm{Y}$ \\
\hline Firm join year FE? & $\mathrm{Y}$ & Y & $\mathrm{Y}$ & Y & $\mathrm{Y}$ & $\mathrm{Y}$ \\
\hline Team size FE? & $\mathrm{N}$ & Y & $\mathrm{N}$ & Y & $\mathrm{N}$ & $\mathrm{Y}$ \\
\hline Sector FE? & $\mathrm{N}$ & Y & $\mathrm{N}$ & Y & $\mathrm{N}$ & $\mathrm{Y}$ \\
\hline Location FE? & $\mathrm{N}$ & Y & $\mathrm{N}$ & Y & $\mathrm{N}$ & $\mathrm{Y}$ \\
\hline
\end{tabular}

